\title{
A Magyar Királyi Csendőrség a dualizmuskori Magyar Királyság határőrizetében 1891-1918
}

A csendőrség intézménye Európa egyik legnagyobb múltú, francia indíttatású katonailag szervezett fegyveres örtestülete, melyet a francia kutatók a XII. századig vezetnek vissza. A rendvédelmi testület kezdetben Maréchaussée néven a francia haderőn belüli rendet tartotta fenn. Fokozatosan — a lakosság kezdeményezéséra — terjesztették ki a kitünő hatásfokkal tevékenykedő szervezet hatáskörét békeidőszakban is a hadmüveleti területen kívül eső térségekre és az ott élő polgári lakosságra. A testület elnevezését a „nagy francia forradalom” elött változtatták csendőrségre. A forradalom alatt a szervezetet ugyan feloszlatták, azonban gyorsan kiderült, hogy arra szükség volt így újjászervezték. A testületet NAPÓLEON Buonaparte modernizálta. NAPÓLEON uralkodása alatt a Francia Császárság vonzáskörébe tartozó vazallus államokba exportált francia polgári közigazgatási minta részeként terjedt el a csendőrség intézménye. NAPÓLEON bukása után azonban a testületeket nem oszlatták fel, mivel azok kitünő hatásfokkal müködtek. A XIX. században Európa valamennyi országában bevezették a csendőrség intézményét. ${ }^{1}$

A csendőrség intézménye Ausztrián keresztül érkezett Magyarországra. NAPÓLEON Buonaparte tündöklése időszakában — a korábban hagyományosan a HABSBURG-birodalomhoz tartozó Lombardiára is kiterjedt a francia befolyási övezet, így ott is bevezették a francia közigazgatási modell részeként a csendőrséget. NAPÓLEON bukását követően pedig, amikor a tartományt a HABSBURGok visszakapták a csendőrséget megtartották, mivel az kitünő eredményességgel müködött. ${ }^{2}$

Az Olmütz-i oktrojált birodalmi alkotmány pedig már azt tartalmazta, hogy „ . . . a birodalom belsö rendjének a védelme birodalmi ügy . . . „ A neoabszolutizmus rendvédelmi struktúráját ennek a szellemében alakította ki Ferenc József, dr. Alexander BACH birodalmi belügyminiszter vezetésével. A magyar nemzet felszámolására törekvő, az ország függetlenségét eltörlő idegen elnyomó hatalom rendvédelmi modelljének vált az egyik szervezetévé a birodalmi csendőrség, amely a Kárpát-medence területén - több tartományra felosztott - Magyar Királyság területén is müködött. ${ }^{3}$ Ez a szervezet azonban nem csupán a rend fenntartásában, hanem a magyar nemzet elnyomásában is jeleskedett. Ebböl fakadóan pedig nem csupán a lakosság ellenszenvét vívta ki, hanem a magyar politikai vezetés sem volt hajlandó a kiegyezéskor a birodalmi csendőrségnek a Kárpát-medence térségében állomásozó alakulatait az újjászerveződő magyar állam rendvédelmi modelljébe befogadni. ${ }^{4}$

A kiegyezéssel tehát a Magyar Szent Korona alá tartozó területeken a birodalmi csendőrség megszünt ugyan, azonban Horvátországban és Erdélyben — a közös haderő szervezetében — egy-egy csendőr ezred fennmaradt. ${ }^{5}$ Viszonylag gyorsan kiderült azonban, hogy az önkormányzati rendörségek — a nagyvárosok kivételével — képtelenek fenntartani a rendet. ${ }^{6}$ Ezért TiszA Kálmán miniszterelnök kezdeményezésére a magyar kormány átvette az erdélyi és a horvátországi csendőr ezredeket a közös haderőtől 1876-ban, majd 1881-ben felállították a Magyar Királyi Csendőrsséget. ${ }^{7}$ Ez nem az első kezdeményezés volt a magyar csendőrség létrehozására. A reformkorban a felsőház tagjai már megkísérelték a magyar csendőrség létrehozását. Akkor azonban ez a gondolat nem találkozott az uralkodó egyetértésével, így a téma elhalt. ${ }^{\mathbf{8}}$

Egy évtized leforgása alatt a Magyar Királyi Csendőrség a magyar rendvédelmi modell legerősebb és legeredményesebb szervezetévé vált. Megteremtette a vidék közbiztonságát és azt jó színvonalon fenn is tartotta. Nem csupán a falvak, hanem a városok is szerették volna, ha a hatósági területükön csendőr csapatok állomásoztak volna. Ezért a csendőrség disszlokációját számos alkalommal módosították, melynek az volt a lényege, hogy a meglévő testületi létszámot (12 000 fö) minél több helyre osszák szét. ${ }^{9}$ A városok számára pedig törvényi úton engedélyezték, hogy — a testülettel kötött szerződés nyomán, költségtérítéses formában - kérésükre a Magyar Királyi Csendőrség hatósági területükön is tevékenykedjen. Ezzel a lehetőséggel számos város élt is oly módon, hogy külterületén a rend fenntartására a Magyar Királyi Csendőrséget kérte fel. ${ }^{\mathbf{1 0}}$

A polgári magyar állam rendvédelmi modellje a dualizmus időszakában alakult ki, amely kisebbnagyobb módosításokkal a két világháború között tovább élt. E rendvédelmi modell integráns részét alkotta, a kiegyezés után ugyancsak újjáformálódó magyar határörizet.

A magyar határőrizet és határvédelem hagyományosan uralkodói közvetlen kompetenciába tartozott és a határvédelmi, valamint a határőrizeti szervezet nem vált el egymástól. A XVIII. és a

XIX. században azonban az ipari forradalom nyomán a haditechnika jelentős mértékben fejlődött és megjelentek a sorozáson alapuló tömeghadseregek is. Ebböl fakadóan a háborúk védelmi és támadó müveleteiben szélességében és mélységében tagozódott kellő mennyiségü és minőségü haditechnika és élőerő koncentrálásával lehetett eredményre jutni. Ezt a témát Karl von CLAUSEWITZ részletesen 
is megjelent a XX. század kezdetén. ${ }^{11}$

A helyzet tehát abban az értelemben változott, hogy a határőrizeti feladatokat ellátó katonai alakulatok tehertételt jelentettek az ország hadereje tekintetében. A határőrizeti teendők ellátásával megbízott katonai alakulatokat ugyanis nem lehetett koncentrálni, hanem — az eredményes határőrizet megvalósítása érdekében - apró szervezeti egységekre bontva, viszonylag keskeny sávban és hosszan elnyújtva kellett a határ mentén elhelyezni, megfosztva a nehézfegyverzetüktöl, amely csak gátolta volna őket a határőrizeti teendőik ellátásában. Ez a katonai erő azonban elvesztette a védelmi és támadó müveletekben való eredményes részvételének a képességét. Ezért Nyugat-Európában már a XVIII. századdal kezdődően a határok őrzését a haderőtől a rendvédelmi testületek fokozatosan átvették. Az Osztrák-Magyar Monarchiában erre a váltásra a XIX. század második felében, a kiegyezést követően került sor.

Az Osztrák-Magyar Monarchián belüli sajátosságot e témában az jelentette, hogy a határőrizetnek a haderőtől a rendvédelmi testületekhez kerülése egyúttal ezt eredményezte, hogy a határőrizet a közös ügyek csoportjának gerincét képező hadügytől a két társország, azaz az Osztrák Császárság és a Magyar Királyság belügyét alkotó közigazgatás részévé válva a társországok önálló, egymástól független kompetenciájába került. ${ }^{12}$

Mivel azonban a két társország azaz az Osztrák Császárság és a Magyar Királyság között többékevésbé 10 évente megújításra kerülő vámszövetség müködött, amelyből fakadóan a személyek és az áruk a két társország közös határán bárhol és bármikor szabadon átléphették a határt, ezért határőrizetre csak az Osztrák-Magyar Monarchia külső határain volt szükség. Mindkét társország a saját külső határait őrizte, függetlenül attól, ahogyan a külső határainak az őrzését a dualista államalakulat társállama megvalósította. A Magyar Királyság tekintetében ez azt jelentette, hogy a magyar-román és a magyar-szerb határon kellett határőrizetet megvalósítani. A dualizmuskori magyar határőrizeti szervezetek e két határszakaszra koncentrálva alakultak ki, majd fejlődtek. ${ }^{13}$

Kezdetben a magyar határőrizet teendői a helyi közigazgatás szervezetei és a Magyar Királyi Pénzügyőrség vámhatár szakasszal rendelkező őrsei között oszlottak meg. Ahogyan azonban az önkormányzati rendvédelmi testületekre alapozott rendvédelmi modell megbukott Magyarország belterületén, ugyanúgy alkalmatlannak bizonyult ez a modell a határok örizete terén is. Kezdetben ugyanis a vámhatárvonallal rendelkező járások létesítettek úgynevezett szolgabírói kirendeltségeket a határ mentén, amelyek feladatát a határrend betartatása alkotta. A határforgalom ellenőrzése céljából pedig a határátkelőhelyekhez — korabeli szóhasználat szerint a határkapukhoz — legközelebb eső városi rendörségekböl kikülönített csoportot vezényeltek az úti okmányok ellenőrzése céljából. A „zöldhatár” örzését pedig a Magyar Királyi Pénzügyőrség vámhatárvonallal rendelkező szakaszai látták el a saját vámhatárvonalukon. A XIX. század nyolcvanas éveiben azonban egyértelművé vált, hogy ez a szisztéma nem eléggé hatékony, bár kétségtelenül takarékos megoldás. A határ menti közbiztonság és az állategészségügy helyzete volt a legdrámaibb. Ekkora ugyanis Magyarországon már kiépült az állami állatorvosi rendszer, amelynek a következményeként a magyarországi állatállomány jóval egészségesebb volt, mint a vámhatárokon túli térségekben. Ezért pedig a kontinens nyugati felében jó áron eladható volt. Ezt a helyzetet - elsősorban Erdélyben — veszélyeztette a kevésbé ellenőrzött államhatáron megvalósuló illegális állatforgalom. Emellett pedig a határ menti elhagyott helyeken - nemegyszer a fakitermelő és egyéb munkások között — bünözők és a mai fogalmaink szerinti terroristák is igyekeztek megbújni. Feltétlenül szükségessé vált, hogy a magyar kormányok az ország belsejéhez hasonló közbiztonsági állapotokat hozzanak létre a Magyar Királyság vámhatárok menti térségében is. ${ }^{14}$

Magától értetődő volt a kortársak számára, hogy a határőrizetet újjá kell szervezni és az újjászervezésnek a centralizmus mentén kell megvalósulnia, hiszen a gondok forrása éppen az volt, hogy a kiegyezés után kialakított határőrizeti rendszer jelentős mértékben támaszkodott az önkormányzati közigazgatás rendvédelmi szervezeteire. Igaz azonban, hogy ekkor még a Magyar Királyi Pénzügyörségen kívül nem is volt a magyar kormányzatnak közvetlenül alárendelt olyan rendvédelmi testülete, amelyre a határőrizeti teendőket rá lehetett volna bízni. Kézenfekvő volt, hogy a magyar közbiztonság terén hathatós pozitív fejlődést létrehozó új magyar rendvédelmi testületet a Magyar Királyi Csendőrséget kell bevonni a magyar határőrizet fejlesztésébe. Az európai és a magyar tapasztalatok egyaránt azt mutatták, hogy a csendőrség a nemzeti rendvédelmi modellek legeredményesebb szervezete. A magyar határőrizeti rendszerből egyrészt hiányzott a katonailag szervezett őrtestület, másrészt pedig a viszonylag nagyobb létszám igénybe vételének a lehetőségét is nélkülözte a magyar határőrizeti struktúra. Ez a létszámhiány és széttagoltság volt a magyar határőrizet gyenge pontja, ugyanis ez tette lehetővé, hogy a „zöldhatáron” ellenőrizetlenül kelhessenek át az arra illetékte- 
lenek. Ezt a helyzetet kívánta a magyar kormányzat orvosolni a határszéli csendőrség létrehozásával 1891-ben. ${ }^{15}$ Ehhez kapcsolódott, hogy a magyar-román határ geodéziai kitüzése befejeződött a nyolcvanas években és a határjelek karbantartásával, továbbá a határvonallal kapcsolatos közös teendőkről a magyar és a román kormány megegyezett, mely szerződést mindkét ország törvénybe iktatott. ${ }^{16}$

A határőrizeti teendőket a kortársak fontos és összetett feladatnak tekintették. A határőrizeti utasítást hat tárca képviselöje írta alá. ${ }^{17}$

Az utasítás - amely a polgári magyar állam első, komplex értelemben vett határőrizeti utasításának tekinthető - öt fö fejezetböl állt:

- „I. A határ épségben tartására való felügyelet és a határon való közlekedés . . .;

- II. A határfolyókra és határkapukra vonatkozó határozványok végrehajtása . . .;

- III. Az erdő-átvágások tisztán tartása ...;

- IV. állategészségügy ...;

- V. a pénzügyörség szolgálatának szabályozása. . . ${ }^{18}$

A közös miniszteri rendelet formájában megjelenő és 43 §-ból álló határőrizeti utasítás első §-a tartalmazza a határszéli csendőrség felállítását. ${ }^{19}$ A határszéli csendőrség nem volt önálló rendvédelmi testület, hanem a Magyar Királyi Csendőrség részét alkotta. Lényegében a mai fogalmaink szerinti szolgálati ágat alkotott. A Magyar Szent Korona alá tartozó területeken egy csendőrség müködött a Magyar Királyi Csendőrség. A Horvát-Szlavón Csendőrség is a Magyar Királyi Csendőrségen belüli szervezet volt, bár autonóm módon müködött a horvát törvényhozás felügyeletével és kormányzat irányításával. Az Osztrák-Magyar Monarchia társországában az Osztrák Császárságban az Osztrák Császári Csendőrség müködött az Osztrák Császárság vidéki területére kiterjedően. Az OsztrákMagyar Monarchiában e két csendör szervezet tevékenykedett a két kormány, illetve országgyülés felügyeletével. Volt azonban még egy csendőrség, a bosnyák csendőrség. Bosznia-Hercegovina azonban nem tartozott sem az Osztrák Császársághoz, sem pedig a Magyar Királysághoz. A tartományt az Osztrák-Magyar Monarchia két társországa közösen irányította a közös pénzügyminiszter által. Az 1878-ban okkupált tartományt az Osztrák-Magyar Monarchia 1908-ban annektálta. A tartományba az életet az Osztrák-Magyar Monarchia viszonyai szerint szervezték meg a pénzrendszertől a mértékrendszeren át a közigazgatásig. A közös pénzügyminiszter BoszniaHercegovina témájában nem a delegációknak, hanem közvetlenül a két társország törvényhozásának tartozott felelősséggel. Hadügyi témában pedig a tartományban is ugyanúgy érvényesült az uralkodói kompetencia, mint a két társország esetében. 1910-ben Bosznia-Hercegovina alkotmányt is kapott, amely lényegében tartományi szervezeti szabályzat volt. A legfelsőbb igazgatásért a továbbiakban is a közös pénzügyminiszter felelt az Osztrák-Magyar Monarchia két törvényhozásának az illetékességi körében. A tartományi gyülésnek felelös tartományi közigazgatás csak a tartomány belső életével kapcsolatos témákban járhatott el. Bosznia-Hercegovina helyzetéből fakadóan rendelkezett a tartomány önálló csendőrséggel, amely nem tartozott sem a Magyar Királyi Csendőrséghez, sem pedig az Osztrák Császári Csendőrséghez. Az Osztrák-Magyar Monarchia két társországa és BoszniaHercegovina közös határain ugyanúgy szabad volt a személyek és árúk mozgása, mint az Osztrák Császárság és a Magyar Királyság közös határain. A tartomány pedig a az Osztrák-Magyar Monarchiával nem közös határait — közigazgatása részeként - ugyanúgy önállóan örizte, mint a Magyar Királyság vagy az Osztrák Császárság. ${ }^{20}$

A határszéli csendőrség szervezetét eleve csupán a magyar-román és a magyar-szerb határon építették ki. A határszéli csendőrség szervezeti egységeinek a diszlokációját a honvédelmi és a belügyi tárca közös bizottsága állapította meg, mely bizottságot TÖRÖK Ferenc altbgy. a Magyar Királyi Csendőrség felügyelője vezette. A határszéli csendőrség 1893 júliusában kezdte el szolgálata ellátását. A határszéli csendőrséget a Magyar Királyi Csendőrség két csendőr kerületében szervezték a kolozsvári és szegedi székhelyü erdélyi, illetve dél-alföldi vármegyékre kiterjedő csendőr kerületekben. A határszéli csendőrség felállításakor a kolozsvári székhelyü csendőr kerület 5 szárny- és 11 szakasz-parancsnoksággal, valamint 134 örssel , továbbá 4 állandó különítménnyel müködött és összesen 985 főnyi legénységgel rendelkezett. Az átszervezés nyomán a csendör kerület 1 szárnnyal, 2 szakasszal, 12 őrssel és 66 főnyi személyzettel (3 tiszt, 3 őrmester, 12 örsvezetö, 48 csendőr) gyarapodott. A csendőr kerület szervezeti egységei és személyi állománya tekintetében tehát koránt sem elhanyagolható erősítést kapott a határórizeti feladatai eredményes kivitelezése érdekében. Hasonló mértékü erősítést kapott a szegedi székhelyü csendőr kerület is, ahol — a korábbi határ menti őrsökkel együtt — a határ mentén 42 örs müködött a határszéli csendőrség létrehozása nyomán. Ezen örsökön szolgálatot teljesítő legénységi állomány létszámát pedig 149 före növelték. A szegedi csendőr kerület 
határőrizeti szisztémája némileg eltért a kolozsvári csendőr kerületétől. A vízi határszakasszal rendelkező szegedi csendőr kerületnél ugyanis nem hoztak létre új szárnyat, illetve szakaszokat a határőrizeti feladatok eredményes teljesítése érdekében. A dél-alföldi csendőr kerület szervezetében az új őrsöket a határszakasszal rendelkező meglévő szakasz-parancsnokságok alárendeltségébe helyezték. ${ }^{21}$

Mindkét csendör kerület esetében nőtt azonban a határ menti őrsök száma és jelentősen gyarapodott a határörizeti feladatokat ellátó csendőrök létszáma is. Emellett pedig mindkét kerületparancsnokságon rendszeresítettek egy-egy tiszti státuszt a kerület határőrizeti teendőinek az irányítása céljából.

A Magyar Királyi Csendőrség 12000 főnyi létszámából összesen 320 fö látott el határőrizeti feladatokat a határszéli csendőrség felállítása nyomán, amely a testület teljes személyi állományának $2,66 \%$-át alkotta. Ez a létszám nem nevezhető jelentősnek sem a magyar rendvédelmi testületek összlétszámához, ${ }^{22}$ sem a feladatkörhöz, sem pedig az őrzendő határvonal hosszához viszonyítva. ${ }^{23}$

A határszéli csendőrség létrehozásával azonban - annak ellenére, hogy a határcsendőri létszám csekély volt - jelentősen megváltozott a magyar határőrizet helyzete a magyar-román és a magyarszerb határszakaszokon. Egyrészt ugyanis a magyar határőrizet korábbi létszámához viszonyítva amelyben a legtekintélyesebb létszámú élőerőt a Magyar Királyi Pénzügyőrség vámhatárvonallal rendelkező szakaszain szolgálatot teljesítő mintegy 300 fő pénzügyőr alkotta — a 215 fő is jelentősnek tekinthetö. ${ }^{24}$

Másrészt a Magyar Királyi Csendőrség és a korabeli magyar rendvédelem elit alakulata volt, mivel:

- a személyi állomány képzettsége, szakmai felkészültsége jelentősen felülmúlta a magyar rendőrségeket, amelyek zömükben önkormányzati rendőrségek voltak, ahol a legénységi állomány közel $20 \%$-a írástudatlan volt, rendőrségek tiszti kara pedig járatlan volt a rendőri erők vezetésében, mivel többnyire csupán jogakadémiai végzettséggel, illetve — az alacsonyabb beosztások esetében érettségivel rendelkezett, ezzel szemben pedig a Magyar Királyi Csendőrség legénységi állománya katonaviselt, elemi iskolai végzettségü, egységes és színvonalas szakmai felkészültségü és permanens továbbképzés alatt álló személyi állományt alkotott, melyet Ludovika Akadémiát végzett tisztek nevezettek, akik járatosak voltak a katonai vezetéstudomány gyakorlati alkalmazásában, emellett pedig a csendörökkel szembeni elvárás volt az is, hogy a magyar nyelv mellett beszéljék azt a nyelvet is, amely a szolgálati helyükön a lakosság anyanyelve volt;

- a csendőrség személyi állománya egységes felszereléssel és fegyverzettel rendelkezett ellentétben a rendőrségekkel, ahol az egyenruha és a rangrendszer városonként eltérő volt, továbbá a rendörök saját maguk szerezték be fegyvereiket, ebböl fakadóan pedig a legolcsóbb és a használthatatlanság határát súroló tarka fegyverekkel rendelkeztek;

- a csendőrséget egységes és korszerü, jól bevált elvek szerint vezették, egységes szolgálati szabályzatok szerint, ellentétben a rendőrségekkel, ahol, városonként változott a szolgálati szabályzat;

- mivel a csendőrségnél nem a hivatali illetve a gyári — többé-kevésbé napi 8 órai elfoglaltságot jelentő - munkarendet alkalmazták, a személyi állományt sokkal hatékonyabban tudták alkalmazni, mivel az átlagos szolgálati idő általában 16 óra volt, természetesen pihenők beiktatásával;

- a csendőrség személyi állományának a szolgálati morálja is kiváló volt, ugyanis már a felvételi eljárások során is figyelembe vették a jelentkezőknek hazaszeretethez füződő viszonyát, a kiképzés is hazaszeretet orientált volt, illetve a testületen belül is a nemzethüség szelleme dominált, emellett pedig a testületi tagok — az állami alkalmazottak ellátásával összhangban — olyan ellátásban részesültek, amely okafogyottá tette a korrupcióra való hajlamot, mindez pedig a rendőrségek esetében nem, vagy csupán csökevényes formában érvényesült;

- a magyar csendőr testület ezen pozitív vonásait foglalta keretbe a katonai szervezettség, amely az előnyös vonásokat felerősítette és jól alkalmazhatóvá tette. ${ }^{25}$

Ezen körülmények ismeretének a birtokában érthető, hogy a kortársak úgy fogalmaztak „Egy csendőr felér több rendőrrel." ami alatt nem csupán a rendőröket, hanem általában a társ rendvédelmi testületek tagjait értették.

A határszéli csendőrség kialakításának az időszakában a Magyar Királyságnak az útlevél és vámköteles határszakaszain összesen 996 fő teljesített szolgálatot. Ezen létszám 22,69 \%-a, azaz 226 fö - 151 fó vámhivatali, 39 fö vesztegintézeti, 36 fó egészségügyi állomási munkatárs — fegyver nélkül tevékenykedett. Fegyveres szolgálatot a Magyar Királyi Pénzügyőrség vámhatárvonallal rendelkezö szakaszaihoz beosztott pénzügyörök, valamint a magyar-román és a magyar-szerb határ menti erdőségekben tevékenykedő mintegy 200 főnyi vadászfegyverrel rendelkező erdőhatósági munkatárs látott el. Az erdőhatósági munkatársak azonban nem kifejezetten határőrizeti szolgálatot teljesítettek. 
Az ő határőrizeti kötelezettségüket csupán az alkotta, hogy az erdőjárásaik során a gyanús idegeneket elfogják és a legközelebbi hatóságnak átadják. Ily módon tehát az érintett „zöldhatár” szakaszok örzését lényegében 450 fö pénzügyőr és - a határszéli csendőrség létrehozása után - 320 fö csendőr, azaz összesen 770 fö látta el. ${ }^{26}$ (I.sz. melléklet)

A határszéli csendőrség felállítása nyomán tehát az alaphelyzet nem változott abban a tekintetben, hogy a magyar határőrizet derékhada a kormány közvetlen irányítása alatt álló rendvédelmi testületek személyi állományából került ki, azonban a helyi önkormányzatok — a szolgabírói kirendeltségek és a határátkelöhelyekhez közeli városok önkormányzati rendőrségeinek személyi állományából a határforgalomban résztvevő utasoknak az ellenőrzése céljából kikülönített rendőri csoportok által — továbbra is kulcsszerepet töltöttek be a határörizetben. A szolgabírói kirendeltségek hatásköre ugyanis 1891 után sem mérséklődött. Továbbra is az alapfeladatukat alkotta a határrend, illetve a határörizeti tevékenységet megvalósító szervezetek felügyelete. Érdekes helyzet állt elö, mivel a tényleges fegyveres határőrizeti feladatokat ellátó szervezetek munkatársai határőrizeti teendőiket a más irányú alapfeladataik mellett látták el. A vámhatár menti pénzügyőri szakaszok pénzügyőrei a jövedéki és egyedárúság ellenőrzésével kapcsolatos teendőiket, illetve a határszéli csendőr őrsök csendőrei a közbiztonsággal kapcsolatos teendőiket ugyanúgy ellátták mint az ország belsejében szolgálatot teljesítő testületi társaik. E teendőik mellett végezték el a határőrizeti feladataikat is. A szolgabírói kirendeltség pedig — melyeket „csupán” részhatárőrizeti teendők végzése céljából hoztak létre és más irányú közigazgatási feladatokat sem kaptak — önkormányzati szervezetek képviseletében felügyelték a központi államhatalom által közvetlenül irányított szervezetek határörizeti teendöit. A magyar közigazgatás azon szervezeti egységei, a határ menti szolgabírói kirendeltségek tehát, amelyeket kifejezetten a határőrizeti teendők megvalósítása érdekében létesítettek, csupán részhatárőrizeti feladatokat láttak el, a csekély létszámukból és a civil jellegükből fakadóan másra nem is voltak alkalmasak. A határőrizeti teendök derékhadát pedig azaz a „zöldhatár” örizetét a központi államhatalomnak közvetlenül alárendelt rendvédelmi testületek határ menti alakulatai végezték a testületi alapfeladataik ellátása mellett. ${ }^{27}$

Egyértelmü, hogy a határszéli csendőrség felállításával a belügyi tárca is szerepet kapott a magyar határőrizetben, így a vámhatár orientáltság mellett megjelent a közbiztonsági dominancia is, amely a későbbiek során tovább erősödött.

A korábbi egylépcsős határőrzés - amelyet „csupán” a határ menti pénzügyőr csapatok valósítottak meg - kétlépcsőssé vált, melyet a pénzügyőrség és a csendőrség határ menti alakulatai valósítottak meg. Mindkét lépcsőn belül — a korábbi gyakorlatot megőrizve, illetve átvéve — pedig több vonalas határőrizet valósult meg a feltételezett határsértők valószínűsített mozgási térségében és idejében. Ez a mélységében differenciáltan tagolt határőrzés sokkal eredményesebb volt, mint a korábbi egylépcsős változat.

A Magyar Királyi Csendőrség bevonása a magyar határörizetbe e tevékenységet kétség kívül eredményesebbé tette. A magyar határörizeti rendszer müködése során azonban keletkeztek olyan tapasztalatok is, amelyre az illetéseknek előbb-utóbb reagálniuk kellett. A magyar határórizeti modell müködése során nyilvánvalóvá vált, hogy:

- a vám- és útlevéköteles határvonalak biztonságos őrzésével jóval nagyobb létszámú személyi állományra van szükség mint amit a századfordulón erre a célra a magyar állam biztosított;

- a helyi önkormányzatok határ menti kirendeltségei csupán korlátozottan alkalmasak több rendvédelmi fegyveres őrtestület határőrizeti tevékenységének az eredményes összehangolására;

- a XIX-XX. század fordulóján a határőrizethez is kapcsolódóan olyan bőséges jogi szabályozás született — például az idegenrendészet, a kivándorlás, a csempészés stb. témáiban - , hogy indokolttá vált kizárólag a szaktevékenységre vonatkozó hatáskörrel rendelkező fegyveres rendvédelmi szakmai szervezet létrehozása.

E helyzetre reagálva hozta létre a magyar országgyülés - kivándorlásra, a határörizetre, a határforgalom ellenőrzésére és az útlevélre vonatkozó 1903. évi törvénycsomag részeként — a határrendőrség létrehozására vonatkozó törvényt. ${ }^{28} \mathrm{~A}$ testületet pedig az 1906 . év elején fel is állították. A Magyar Királyi Határrendőrség átvette a határszéli szolgabírói kirendeltségek feladatát, így a magyar határőrizeti modellből az önkormányzatok kikerültek, mivel a határrendőrség egyben kiváltotta azokat a rendőri kirendeltségeket is, amelyek a határkapuknál a távolsági határforgalom ellenőrzését végezték. E teendőket a Magyar Királyi Határrendőrség a továbbiakban saját hatáskörében a saját személyi állományával látta el. ${ }^{29}$

A Magyar Királyi Határrendőrség létrehozása kétség kívül javulást idézett elő a magyar határörizeti modellben, azonban nem oldott meg minden gondot és új nehézségek is keletkeztek. 
Továbbra is nehézséget okozott a határőrizetbe bevont csekély számú élőerő. A Magyar Királyi Határrendőrség személyi állománya ugyanis szükös volt, még a háború időszakában jelentősen felduzzasztott létszám is csupán 500 fö körül alakult. ${ }^{30}$

Az 1903. évi törvénycsomag részeként alkotott és a Magyar Királyi Csendörségre vonatkozó törvény azonban hozzájárult a határőrizeti feladatokat teljesítő csendőri létszám gyarapításához. ${ }^{31}$

Új ellentéteket generált azonban a Magyar Királyi Határrendőrség magyar határőrizeti modellben betöltött vezető szerepének az értelmezése. A Magyar Királyi Csendőrség részéről jogos ellenérzést váltott ki, amikor a határszéli csendőrség erőit a Magyar Királyi Határrendőrség alárendelt, az irányítása alá tartozó alakulatként igyekezett kezelni. A határszéli csendőrség felállítását elrendelő közös miniszteri rendeletben is az állt, hogy a személyi- és vagyonbiztonság ellátása „ . . . a határvonalon . . . az erre külön szervezendő Magyar Királyi Csendőrséget illeti és pedig elöljáró tisztjeinek s az érdekelt vármegyei törvényhatóságoknak egyetértő felügyelete alatt.” 32 A magyar államigazgatást megosztotta a határőrizet fejlesztése, illetve abban új testületként a Magyar Királyi Határrendőrség létrehozása. Voltak, akik - egyébként nem alaptalanul, hiszen a határrendőrség számos felhatalmazást kapott a határ menti rendvédelmi testületek igénybevétele tekintetében — úgy értelmezték a helyzetet, hogy a határszéli csendőrség a Magyar Királyi Határrendőrség alárendeltségébe került. A határrendőrség számára is szimpatikusnak tünhetett ez a felfogás, mivel a csendörség tiszti kara részéről számos panasz érkezett a Magyar Királyi Határrendőrségre vonatkozóan a belügyi tárcához ebben a témakörben. A Magyar Királyi Határrendörségnél ugyan 1908 és 1912 között megkíséreltek határrendőr őrsöket létrehozni, ezek a szervezetek azonban nem voltak képesek helyettesíteni a határszéli csendőrséget, legfeljebb a határkapuk őrzése körüli teendők ellátását tudták megvalósítani.

A határszéli csendőrség és a határrendőrség viszonyát tisztázni kellett. A tiszta viszonyok megteremtése nem csupán a határőrizet, hanem a határvédelem miatt is szükségessé vált. 1912-ben a magyar országgyülés - a közös haderö többszöri sürgetésére - megalkotta a kivételes hatalomról szóló törvényt. ${ }^{33}$ Ebből fakadóan a haderő, a Magyar Királyság területén is hozzálátott a határvidék fegyveres konfliktusra való felkészítéséhez. Ennek az előkészítésnek pedig az egyik kiindulópontja az volt, hogy békeidőszakban mely szervezet milyen jellegü határőrizeti feladatot teljesít, mivel erre alapozva lehetett a katonai határőrizeti feladatokra való felkészülést előkészíteni és megszervezni.

A Magyar Királyi Csendőrség OLÁH Ödön vezetésével csendőr tiszti delegációt küldött az Osztrák Császárságba és Bosznia-Hercegovinába azzal a céllal, hogy tanulmányozzák az ottani csendőrségnek a határőrizetben betöltött szerepét és tegyenek javaslatot a kedvező tapasztalatok hazai adaptálására. A csendőr tiszti delegáció indítványának a figyelembe vételével alakították át a magyar határőrizeti modellt, amely már tekintettel volt a társország tapasztalataira, illetve a haderőnek a katonai határőrizet kialakítására vonatkozó elgondolására is. Ezen elgondolás kivitelezésének a tervei az osztrák örökös tartományokban már elkészültek és a kivitelezési teendők is elkezdődtek. ${ }^{34}$

A határszéli csendőrség átszervezésének — amely egyébként a „szolgálati ág” 1891-től 1918-ig tartó történetében a legjelentősebb átszervezést jelentette — az volt a lényege, hogy:

- gyarapították a határszéli csendőrségben szolgálatot teljesítő csendőrök létszámát;

- egységesítették a határszéli csendőrség szervezeti felépítését;

- egyszerüsítették és hatékonyabbá tették a „szolgálati ág” parancsnokságait;

- elhatárolták a társ határôrizeti szervezetektől a határszéli csendőrség teendőit, egyben pedig a feladatokat egyértelmüvé tették, az együttmüködési teendőket is beleértve;

- a határszéli csendőrség feladatrendszereit illetve az abból fakadó teendőket - hasznosítva a „szolgálati ág” két évtizedes fejlődéstörténetének a tapasztalatait — részletekbe menően szabályozták az 1912. évi kiadású „Csendörségi Szolgálati Utasitás”-ban, annak titkos függelékében pedig az Evidenzbüro-hoz füződő viszonyának gyakorlati teendőit pontosítottták. ${ }^{35}$

Ennek nyomán a magyar határőrizeti modell hatékonysága növekedett, a Magyar Királyi Csendőrségnek a határőrizetben betöltött szerepe pedig mindenki számára egyértelművé vált, továbbá a véderő is olyan szilárd kiindulási alaphoz juthatott, amelyre támaszkodva hozzákezdhetett a határvidék háborús időszakra történő felkészítéséhez.

A határszéli csendőrség 1912. évi fejlesztése nyomán a „szolgálati ágnál” összesen 1392 fö teljesített szolgálatot, 458 csendőr a magyar-szerb, 934 csendőr pedig a magyar-román határon. Ez a lét-szám a szerb határon 55 örsön, míg a román határon 131 őrsön teljesített szolgálatot. A 12000 fős Magyar Királyi Csendőrség személyi állományának 11,6 \%-a állomásozott a Magyar Királyság útlevélköteles határszakaszán ellátva a „zöldhatárőrizeti” teendőket is a Magyar Királyi Pénzügyőrség vámhatárvonallal rendelkező szakaszainál szolgálatot teljesítő pénzügyőrökkel együttműködve. ${ }^{36}$ (II.sz. melléklet) 
A határszéli csendőrség szervezeti felépítését úgy módosították, hogy az érintett csendőr kerületparancsnokságokban meghagyták a határőrizeti referens törzstiszti státuszát, azonban közte és a határszéli csendőr őrsök között a kétszintü parancsnokságokat, azaz a szakasz- és szárny-parancsnokságokat megszüntették, helyükbe pedig egy vezetési szintet rendszeresítettek a kikülönített törzstisztek formájában, akik a határszéli csendőr őrsök és a csendőr kerület-parancsnokságok határőrizeti referensei között az egyetlen parancsnoki szintet alkották. Fegyelmi és anyagi ellátás tekintetében ugyan az érintett szakasz- és szárny-parancsnokságok kompetenciái megmaradtak, határőrizeti szakmai tekintetben azonban egyértelmüen a kikülönített törzstisztek gyakorolták a vezetést. Mivel pedig a csendőrségi diszlokáció egyik alapelve az volt, hogy parancsnokság nem állhat védelem nélkül, ezért minden csendőr-parancsnokság mellé rendszeresítettek egy kislétszámú csendőr őrsöt. A személyi állománnyal való takarékosság miatt pedig a magasabb szintủ parancsnokságok az egyik alárendelt parancsnokságukkal egy székhelyen, általában egy elhelyezési körletben müködtek. Így volt ez a kikülönített törzstisztek esetében is. Ettől függetlenül azonban a kikülönített törzstisztek közvetlen alárendeltségébe a parancsnoksági székhelyen történő elhelyezéssel segédszemélyzetet is rendszeresítettek. Mindegyik kikülönített törzstiszt mellé segédszemélyzetként beosztottak egy századost mint segédtisztet, egy őrmestert, mint irodai segédszolgálatost, és egy polgári állású irodai szolgát is. ${ }^{37}$ (III.sz. melléklet)

1912-ben külön belügyminiszteri rendeletben szabályozták a határszéli csendörség feladatkörét. Ennek az volt a lényege, hogy az úgynevezett határőrizeti külszolgálatokat — azaz a terepen megvalósított szolgálatokat, amelyek praktikusan a „zöldhatárörizeti” szolgálati teendőket jelentették átvette, illetve tovább folytatta a határszéli csendőrség. Emellett pedig a kisebb forgalmú határkapuknál az úti okmányok ellenőrzésének a teendőit is átvette a határszéli csendőrség, továbbá — a továbbra is erre jogosult hatóságok mellett — kiállíthatott határszéli úti igazolványokat, valamint a vasúti- és hajforgalmat lebonyolító határkapuknál, ahol az utasforgalom ellenőrzését a Magyar Királyi Határrendőrség végezte, a határszéli csendőrség ügyeleti szolgálatot volt köteles adni. ${ }^{38}$

Az 1912. évi csendőrségi szolgálati utasításba már beépültek a határszéli csendőrség sarkalatos teendői. A határszéli csendőrség szolgálati feladatait alkották:

„A) A határon átkelők figyelemmel kísérése, a határ mentén felmerülő — államrendészeti szempontból fontosabb - mozzanatokról és eseményekről tájékozódás szerzése és az észleltekről az illetékes hatósággal való közlése;

B) Államellenes nyomtatványok becsempészésének megakadályozása és feljelentése;

C) Idegen politikai ügynökök megfigyelése;

D) Külföldiek bejelentésére és lakhatására vonatkozó szabályok végrehajtásának ellenőrzése a 48 999/1912. (IV. 13.) BM.kr. és az 58 320/1912. (IV. 13.) BM.kr. meghatározottak szerint;

E) A kémkedés megakadályozása, esetleg a kémek elfogása és az illetékes hatóságoknak való átadása;

F) A szomszédos állam lakói részéről személyek és tárgyak ellen intézett erőszakos támadás meggátlása, különösen pedig katonai védőművek, az ország határainak jelölésére szolgáló határjelek, jelzők, katonai vagy polgári hatóság által felállított földmérési jelek megrongálásának, megsemmisítésének, vagy megváltoztatásának megakadályozása, a tettesek kinyomozása és az illetékes hatóságnak való feljelentése vagy — szükséghez mérten — átadása;

G) Kitíltott, rendőrileg kifogás alá eső és magukat igazolni nem tudó gyanús személyeknek az állam területére szándékolt belépésben való megakadályozása;

H) Nyomozott, vagy valamely büntetendő cselekménnyel gyanúsított és a törvények vagy a fennálló szabályok értelmében elózetesen letartóztatható egyéneknek a határszélen való elfogása.;

I) Tolonczok kísérése;

J) Fegyverek, lőszerek és hadiszerek ki- és bevitelének ellenőrzése, valamint tilalom estén ilyenek és más tiltott tárgyak kivitelének és behozatalának megakadályozása;

K) Hadköteles egyének kiszökésének megakadályozása;

L) Kerítés /nőcsempészet, leánykereskedés/ meggátlása és feljelentése;

M) A határszéli vasúti és gőzhajó állomásokon az államrendészeti és közegészségügyi szabályok betartásának ellenőrzése;

N) A határ szélén lévő szállodák, vendéglök, korcsmák, kávéházak és egyéb nyilvános helyek ellenörzése;

O) Azon határvonalakon, ahol útlevélkötelezettség áll fenn és ahol ez kifejezetten a csendőrségre bízatott, az útlevelek vizsgálata, bélyegtelen határátkelési igazolványok kiállítása;

P) Az útlevélszabályok áthágása, a tilos visszatérésre és külföldiek bejelentésére, valamint lakhatására vonatkozó szabályok megszegése által elkövetett kihágások följelentése; 
R) A csempészet megakadályozása és az erre hivatott közegek támogatása;

S) A tiltott kivándorlás megakadályozása, a kivándorlásról szóló 1909/II.tc. és a vonatkozó 57 000/1909. (VI. 15.) BM. végrehajtási utasítás rendelkezései betartásának ellenőrzése, valamint e törvény megszegése által elkövetett büntettek, vétségek és kihágások feljelentése." ${ }^{39}$

A határszéli csendőrség 1912. évi átszervezése kiterjedt a határőrizeti szolgálat teljesítésének a jellegére is. Korábban a határszéli csendőrség őrseinek a beosztottai ugyanúgy őrjárati beosztás szerint teljesítettek szolgálatot, mint az ország belsejében szolgálatot ellátó bajtársaik. Az örjárati beosztásnak az volt a lényege, hogy a járőr számára meghatározták a szolgálati időt, a mentvonalat, a pihenő és a figyelési helyeket, valamint az ott eltöltendő időt is. Ezzel szemben a határszéli csendőrök számára a figyelési pontokat és a pihenő helyeket továbbá a teljes menetidőt meghatározták ugyan, azonban a figyelési és pihenő pontokon eltöltendő időt és a köztük lévő menetvonalat már a járőrvezető határozta meg. ${ }^{40}$

A Magyar Királyi Csendőrség személyi állományának a fizetése a rendfokozati illetményből, a beosztási illetményből és a korpótlékból (szolgálati idő után járó illetményből) állt. E három összetevős fizetési rendszer lényegében a képzettséget - ez jelentette a rendfokozati illetményt, hiszen a rang a képzettséget tükrözte - a tapasztalatokat (korpótlék) és a felelösséget (beosztási illetmény) honorálta. Ezen illetmények kerültek besorolásba - a tisztek és a hasonló állásúak esetében - a XII állami fizetési osztály egyikébe. Így vált egységessé az állami fizetési rendszer. Emellett azonban a helyi specialitások, illetve speciális szakképzettséget is igénylő teendők végzését pótlékokkal ismerték el. Ilyen volt például a testületi pótlék, amelyet lényegében a hivatalnoki karhoz viszonyított kötöttebb és feszesebb életmódot, valamint a fegyveres szolgálatellátásból fakadó veszélyt kívánták honorálni. A határszéli csendőrség csendőrei határőrizeti pótlékként napi 40 fillér pótlékot is kaptak. A vizsgált időszakban egy csendőr őrmester évi fizetése mintegy 2336 korona volt. Egy napra kivetítve a fizetése 6,4 korona volt. Ami mellett a 40 filléres napi határőrizeti pótlék nem elhanyagolható summát jelentett, mivel évi 146 korona összeget tett ki. ${ }^{41}$

A határszéli csendőrség egyik lényeges feladatát alkotta az Osztrák-Magyar Monarchia hírszerző szervezetével - a haderő kebelében müködtetett — Evidenzbüro-val való együttmüködés a határ menti térségben. Az Evidenzbüro-val a Magyar Királyi Határrendőrség és a határszéli csendörség külön-külön müködött együtt. A Magyar Királyi Csendőrség 1912. évi szolgálati szabályzatát úgynevezett „Titkos függelék”-kel is ellátták, amelyben az Evidenzbüro-val való együttmüködés elveit és konkrét szabályait rögzítették. ${ }^{42}$

Az Evidenzbüro lényegében az Osztrák-Magyar Monarchia hadereje vezérkarának volt a felderítő szervezete, egyben pedig a dualista államalakulat egyetlen hírszerző testülete. Ez azonban nem zárta ki annak a lehetőségét, hogy más szervezetek is végezhettek hírszerzést például a külügy, azonban a hírszerzésre szakosodott testületként az Evidenzbüro volt az egyetlen felderítő testület az Osztrák-Magyar Monarchiában. Az Evidenzbüro döntően a hadmüveleti irányokban folytatott hírszerzést. Egyegy hadmüveleti irányban e tevékenységet — a békeidőszakban a hadtestek vezérkarában létesített felderítő főállomások irányították. A határszéli csendőrség értelemszerüen a területileg illetékes hadtest-parancsnokságok felderítő fóállomásaival állt kapcsolatban. A kapcsolattartás a titoktartás szabályainak a szigorú betartásával valósulhatott meg, kizárólag a kihelyezett törzstiszteken keresztül. ${ }^{43}$

A határszéli csendőrség teendőit az Evidenzbüro-val való együttmüködése keretében szükség esetén a hírszerzők határon való észrevétlen átjuttatásának, illetve rejtett találkozók kivitelezésének a közreműködésében való részvétel, továbbá a túloldali hírszerzők hazai határ menti tevékenységének a megakadályozása, valamint a határ túloldalán a saját hírszerzés végrehajtása alkotta. E cél érdekében saját rezidentúrák kiépítése volt kívánatos a határ túloldalán, melynek feladatát a határ menti közlekedési útvonalak, a nagyobb tömeg, illetve felszerelés raktározására alkalmas épületek, a határ menti fegyveres szervezetek létszáma és fegyverzetük, illetve a parancsnoki állomány felderítése és a sebezhető pontok feltárása alkotta. ${ }^{44}$

A határszéli csendőrségre kitüntetett feladat hárult a katonai határôrizetre történő áttérés időszakában is. A katonai határőrizet alatt a kortársak azt értették, hogy a klasszikus értelemben vett támadó, illetve védelmi müveletek a határ térségében ugyan még nem kezdődtek el, azonban a haderő már felvonult a határ térségében és készen állt a támadó, illetve védelmi tevékenységre. A katonai határörizetre természetesen azokon a határszakaszokon kerülhetett sor, amely szomszédos országokkal az Osztrák-Magyar Monarchia háborús viszonyba került, vagy a hadüzenet rövid időn belül valószínüsíthetővé válhatott.

A katonai határőrizetre való áttérés azonban időt vett igénybe, ezen átmeneti időszakra is fel kellett készülni. A katonai határőrizetre való áttérés terveit a területileg illetékes hadtest-parancs- 
nokságok készítették el. A terveket pedig az illetékes határőrizeti szervezetekkel a terepen egyeztették, illetve pontosították. A hadmüveleti területeken ugyanis a Magyar Királyságban a rendvédelmi testületek a haderő felügyelete alá kerültek. A hátországban viszont a magyar rendvédelmi testületek a kormány, illetve az önkormányzatok irányítása alatt maradtak, mivel a magyar kormány a kivételes hatalom gyakorlásának a brit változatát követte, mely szerint a kivételes hatalmat lényegében a kormány gyakorolta. Ezzel szemben viszont az Osztrák Császárságban — a német mintát követve — a kivételes hatalmat a haderő gyakorolta. ${ }^{45}$

A katonai határőrizetre történő áttérés időszakában a vezető szerep egyértelmüen a határszéli csendőrségre hárult. A haderőnek a határra való felvonulásáig a parancsnoki hatáskört a határszéli csendörség őrseinek a vezetői látták el. Ez a helyzet logikusan következett abból a tényből, hogy a Magyar Királyi Csendőrség személyi állományának tagjai személyükben katonának minősültek és azok a fiatalemberek jelentkezhettek csendőrnek, akik példamutatóan letöltötték a sorkatonai szolgálatukat. Emellett a Magyar Királyi Csendőrség vezetősége úgy intézkedett, hogy a határszéli csendőrség kötelékébe azok a csendőrök kerüljenek, akik fiatalok, nőtlenek és a katonai szolgálatra minden tekintetben alkalmasak. A határszéli csendőrség csendőrei számára pedig a véderő időnként — különböző katonai témakörökben - továbbképzö tanfolyamokat is szervezett.

A határszéli csendőr örsök azonban nem csupán a katonai határörizetre történő áttérés adminisztratív centrumai, hanem annak bázisai is voltak. Az áttérés időszakában ugyanis már lényegében a katonai határőrizet szerint kellett megvalósítani a határok őrzését. Ez azt jelentette, hogy meg kellett akadályozni az ellenséges erők felderítő járőreinek és az esetleges vállalkozások végrehajtásának a céljából áttörni szándékozó katonai alakulatok határátlépését, illetve a honi haderő számára a felvonulási útvonalat jelentő vasútvonalakat és mütárgyakat (hídakat, kereszteződéseket stb.) valamint a jelentős mennyiségü felszerelés illetve személyi állomány befogadására alkalmas építményeket őrizni kellett. Emellett pedig — a lehetőségek függvényében — törekedni kellett a túloldali területek felderítésére, illetve az ottani infrastruktúra rongálására. ${ }^{46}$

Ezen feladatok kivitelezéséhez azonban a békehatárőrizet során foglalkoztatott létszámhoz képest jóval több emberre volt szükség. Ezt a megnövekedett létszámigényt nem tudta biztosítani a helyi pénzügyőr szakaszok személyi állománya. Ezért a határ menti lakosságot mozgósítás esetén nem a mélységi területeken kialakított mozgósítási központokba hívták be, hanem a határszéli csendör őrsökbe. Megszervezték a behívásra kerülö személyi állomány fegyverzetének, felszerelésének a helyi tárolását, illetve amit lehetett átadtak a behívásra kerülők számára még békeidőszakban.

A határszéli csendőr őrsöket igyekeztek úgy kibővíteni, hogy azok alkalmassá váljanak — a békeidőszakhoz képest - lényegesen nagyobb létszám befogadására, illetve védhetővé váljanak. Ezért az elhelyezési körletek gyarapítására — a határszéli csendőr őrsök körül löállásokat és futóárkokat hoztak létre, melyeket drótakadályokkal erősítettek meg. A határszéli csendőr őrsök közvetlen környezetében pedig a rendszeresített személyi lőfegyverek hatásos lőtávolságán belül a terepet megtisztították a kilátást, illetve kilövést akadályozó növényzettől. Az örzendő infrastruktúra hathatós védelme érdekében a határszéli csendőrség irányítása alá kerülő behívottakból vonalszakasz őrségeket, mütárgyőrségeket és tartalékokat kellett képezni a mütárgyak ellen irányuló esetleges támadások eredményes meghiúsítása érdekében. Továbbra is fenn kellett tartani továbbá a járőrözést, melyet két fős járőrök helyett 6-8 fős járőrök láttak el. A túloldali területre lépés pedig már nem volt tiltott, bár a határátlépés csak felderítési célból volt indokolt megvalósítani, hiszen a túloldalon a hazai intézkedésekhez hasonlóan szervezték meg a katonai határórizetet. ${ }^{47}$

A hazai haderő határvonalra történő felvonulása után a térségbe érkező csapatok tisztjei vették át a katonai határőrizet feletti irányítást. Előrenyomulás estében azonban a határszéli csendőrség nem követte a haderőt, hanem a helyén maradt és a hadműveleti záróvonal szerepét töltötte be. Visszavonulás esetén viszont a haderővel együtt a határszéli csendőrség is visszavonult. A katonai határörizetre való áttérés tervezése során követett alapelvek a XX. század elején korszerüek voltak, melyek alkalmazását körültekintően tervezték és igyekeztek azokat gondosan kivitelezni.

A magyar-román és a magyar-szerb határon szolgálatot teljesítő határszéli csendőrök sorsa azonban nem egyformán alakult. A magyar-szerb határ határszéli csendőrei már az I. világháború kezdetén átélték a katonai határőrizetre történő áttérés minden vonzatát. A magyar-román határon szolgálatot teljesítő határszéli csendőröknek azonban más sors jutott. Ezen a határszakaszon nem tértek át a katonai határőrizetre, mivel Románia és az Osztrák-Magyar Monarchia között 1916-ig nem jött létre hadiállapot. 1916-ban azonban a románok úgy gondolták, hogy a központi hatalmak már eléggé legyengültek ahhoz, hogy a támadásukat ne legyenek képesek megtorolni. Ezért az Antant unszolására és a Magyar Királyság területéből a részükre felajánlott tetemes térségek megszerzése reményében 
megtámadták Erdélyt. A váratlan támadás következtében ugyan kezdetben sikereket értek el. Később azonban a központi hatalmak visszavágtak és egész Romániát elfoglalták. A magyar határőrizet erőit a román haderő már az 1916. évi erdélyi betörés elején bekerítette. A magyar határőrizeti testületeknek a magyar-román határ mentén állomásozó személyi állománya már nem tudott visszavonulni. A csekély létszámú békehatárőrizeti magyar határőrizeti erők tartották magukat amíg tudták. Sorsuk a megsemmisülés volt. A román csapatok kiszorítása nyomán a magyar határőrizeti rendszert visszaállították a magyar-román határon, bár az Osztrák-Magyar Monarchia és a legyőzött Román Királyság között — a Kárpátok hágóin túl mintegy 20-25 km-el — olyan új határvonalat jelöltek ki, amely nem kedvezett Erdély meglepetésszerü lerohanásának. Ez a határvonal azonban a központi hatalmak vereségével feledésbe merült, helyét pedig a rabló imperialista trianoni békediktátum által létrehozott, a Magyar Királyságot és a magyar nemzetet megcsonkító határvonal keletkezett a Kárpát-medence belsejében.

A Magyar Királyi Csendőrség nem csupán a Magyar Királyság belterületén a közrend terén ért el eredményeket azáltal, hogy megteremtette és példamutatóan fenntartotta a vidék közbiztonságát, hanem a peremterületeken is döntően e testület által valósult meg az eredményes határörizet a dualizmus időszakában.

$\mathrm{Az}$ önkormányzati rendőrségi modell határőrizetben megvalósuló változata elégtelennek bizonyult, ezért e szakterületen is a csendőrségre támaszkodott a magyar kormány az eredményes határőrizet kialakítása érdekében.

1891-től 1918-ig müködött a határszéli csendőrség a Magyar Királyság útlevél- és vámköteles magyar-román és magyar-szerb határszakaszain. A határszéli csendőrség volt - a mai fogalmaink szerint — a testület első szolgálati ága. A vizsgált időszakban ezt a kifejezést még nem használták. A tábori csendőrség és a járásőrmesterségek, amelyeket a nyomozó szolgálat korai előfutárjának tekinthetünk — később jöttek létre, mint a határszéli csendőrség. ${ }^{48}$

A határszéli csendőrség intenzív fejlődésen esett át, amely több periódusra osztható.

Az első periódus 1891-től 1903-ig azaz a „szolgálati ág” felállításától az újonnan létrehozott csendőr kerületek felállításáig tartott.

- Ezzel az aktussal került be a csendőr szervezet a magyar határőrizeti modellbe.

- A csendőrség határőrizeti feladatokba történő bevonása által a magyar határőrizeti modellben megjelent a pénzügyi tárca mellett a belügyi tárca is, amely egyértelmú bizonyítéka annak, hogy a kortársak az eredményes határőrizet megvalósítását nem csupán gazdasági, hanem közbiztonsági témának is tartották.

Az elsö periódus legfontosabb jellemzöjének az tekinthetö, hogy bebizonyosodott, hogy a csendörségre szükség volt a magyar határörizetben.

A második periódus 1903-től 1912-ig, azaz a határszéli csendőrség átszervezéséig tartott.

- Felemelték a határszéli csendőrség létszámát.

- Nyilvánvalóvá vált, hogy a határörizet triászából (a határrend betartatása, a határforgalom ellenörzése és a ,zöldhatár” örzése) a „zöldhatár” örzése feladatkörének az ellátására a legalkalmasabb a Magyar Királyi Csendőrség.

A második periódus legfontosabb jellemzöje, hogy a magyar határörizeti modellben - a Magyar Királyi Határrendőrség felállitásával - a határszéli csendörség ugyan elvesztette a vezetö szerepét, azonban a ,zöldhatárörizeti” teendők terén a dominanciája megerösödött.

A harmadik periódus 1912-től 1918-ig, a határszéli csendőrség megszünéséig tartott.

- A határszéli csendőrség létszámának a gyarapítását összekapcsolták a szakfeladat eredményes megvalósítását elősegítő speciális szervezeti elemek rendszerbe állításával.

- Módosították - ugyancsak a szakfeladat jobb ellátása érdekében — a határszéli csendörök járőrszolgálatának a jellegét, illetve a katonai határőrizetre való áttérés jegyében tovább erősítették a határszéli csendőrséget.

- Rendezték a határszéli csendőrség társ határőrizeti szervezetekhez füződő viszonyát.

A harmadik periódus legfontosabb jellemzöje a katonai határörizetre való áttérés elökészitése, majd végrehajtása volt. ${ }^{49}$

A .dualizmuskori magyar határőrizeti modellben a határszéli csendőrség megjelenése és szerepének megerősödése eklatáns bizonyítéka annak, hogy a határőrizeti tevékenységek — elsősorban a „zöldhatárőrizet” — terén nem nélkülözhetők a katonailag szervezett fegyveres örtesületek. ${ }^{50}$ 
Jegyzetek:

${ }^{1}$ ÖRY: 75-77.p.

${ }^{2}$ PRESZLY: 18.p.

${ }^{3}$ ZACHAR: Fejezetek az osztrák csendörség történetéböl 1849-1918. 105-109.p.

${ }^{4}$ Idem: A HABSBURG-hatalom és a magyar rendvédelem. 146-149.p.

${ }^{5}$ CsAPÓ: A Magyar Királyi Csendörség története 1881-1914. 13-19.p.

${ }^{6}$ Idem: Ráday Gedeon és a szegedi királyi biztosság. A betyárvilág felszámolása.

${ }^{7} 1881 /$ II.tc. ; $1881 /$ III.tc.

${ }^{8}$ REKTOR: 85-86.p.

9 PARÁDI: A Magyar Királyi Csendôrség. Az elsö magyar polgári, központositott közbiztonsági örtestület 1881-1945. 5153.p. $+93-95 . \mathrm{p}$.

${ }^{10} 1882 /$ X.tc.

${ }^{11}$ Clausewitz

${ }^{12}$ GALÁNTAI: 89-160.p.

${ }_{11}^{13}$ PARÁDI: A dualista Magyarország határőrizeti rendszerének kialakulása.

${ }^{14}$ PARÁDI: A határszéli csendörség 1891-1914.

${ }^{15} 50$ 431/1891. (VII. 1.) BM.r.

${ }_{16}^{16} 1888 /$ XIV.tc.

${ }^{17}$ A határőrizeti utasítást aláíró miniszterek: BARoss Gábor kereskedelemügyi miniszter, gr. BETHLEN András földmüvelésügyi miniszter, br. FeJÉRVÁRY Géza honvédelmi miniszter és a király személye körüli miniszter, gr. SzAPÁRY Gyula miniszterelnök és belügyminiszter, SzILÁGYI Dezső igazságügyi miniszter, WEKERLE Sándor pénzügyminiszter,

BÖLÖNY:214.p. + 218.p. + 231.p. + 284-285.p. + 288.p. + 300-301.p.

${ }^{18} 50$ 431/1891. (VII. 1.) BM.r. op.cit.

${ }^{19}$ Loc.cit. 1. §

${ }^{20}$ GALÁNTAI: op.cit. 135-138.p.

${ }^{21}$ PARÁDI: A határszéli csendörség 1891-1914. op.cit. 44-47.p.

${ }^{22}$ A századelön a Magyar Királyságban müködö önkormányzati és a központi államhatalomnak közvetlenül alárendelt katonailag szervezett fegyveres örtestületek és polgári fegyveres örtestületek összlétszáma 32778 fö volt, amelynek a 215 fö csupán 0,66\%-át tette ki.

PARÁDI: A magyar rendvédelem története. 283.p.

${ }^{23}$ A magyar-román és a magyar-szerb határ teljesen eltérő volt, mivel a magyar-szerb határvonal vízi határszakasz, a magyar-román határvonal pedig hegyi határszakasz volt. Azonban mindkét határszakasz nehezen járható területet alkotott. A magyar-román határszakasz hossza $833,2 \mathrm{~km}$, a magyar-szerb határszakasz hossza pedig $458,26 \mathrm{~km}$, összesen a történelmi Magyarország határainak hosszúsága 4166,02 km. Volt.

SUBA: 25.p.

${ }^{24}$ A XIX. század utolsó negyedében a Magyar Királyság útlevél- és vámköteles határain azaz a magyar-román és a magyar-szerb határszakaszokon mintegy:

- 300 fö pénzügyör;

- 151 fö vámhivatalnok;

- 39 fő vesztegintézeti munkatárs (terményeket és állatokat vizsgáló állomások);

- 36 fö egészségügyi állomási munkatárs (utasok vizsgálatára és szükség esetén karanténba helyezésükre hivatott állomások);

- 200 fö határszéli erdőhatóságok fegyveres tagjai;

- 726 fö összesen teljesített szolgálatot.

PARÁDI: A magyar rendvédelem története. 284.p.

${ }^{25}$ PARÁDI: A Magyar Királyi Csendörség. Az elsö magyar polgári, központositott közbiztonsági örtestület 1881-1945. op.cit. 65-84.p.

${ }^{26}$ PARÁDI: A magyar rendvédelem története. 284.p.

${ }^{27}$ PARÁDI: Pénzügyörség és vámhivatalok a határörizetben. 34-39.p. ； Idem: Csendörség a határörizetben. 58-65.p. ; Idem: Rendörség a határörizetben. 37-43.p.

${ }^{28} 1903 /$ VIII.tc.

${ }^{29}$ 5692/1905. (XII.29.) ME.r. ; 91 000/1905. (XII. 29.) BM.kr.

${ }^{30}$ PARÁDI: A Magyar Királyi Határrendőrség. A magyar határőrizet szakmai vezető testülete.

${ }^{31} 1903$-ban az országgyúlés törvényt hozott arról, hogy a 6 csendör kerületből álló Magyar Királyi Csendőrség szervezetét 9 kerületre kell fejleszteni. Ebből azonban csupán 2 új kerület létrehozása valósult meg. Közülük az egyik azonban a brassói székhelyü volt. A felállitását elrendelő jogszabály preambulumában pedig az indoklásban az szerepelt, hogy az új kerület létrehozásának egyik legmarkánsabb oka a határőrizet hathatósabb kivitelezése.

1903/VII.tc.

${ }^{32} 50$ 431/1891. (VII. 1.) BM.r. op.cit. 1. §

${ }^{33}$ 1912/LXIII.tc.

${ }^{34}$ PARÁDI: A határszéli csendörség 1891-1914. op.cit. 49.p.

${ }^{35}$ SZUT-1912. ; SZUT-1912 Titkos függelék.

${ }^{36}$ PARÁAI: A határszéli csendörség 1891-1914. op.cit. 47-48.p.

${ }^{37}$ PARÁDI: A Magyar Királyi Csendőrség határörizeti szolgálata.

${ }^{38}$ 1912-töl a határszéli csendőrség:

- úti okmány vizsgálatot tartott a vodiczai, verestoronyi, predeáli, sósmezői, gyimesbükki és gyergyótölgyesi határkapuknál;

- határszéli úti igazolványokat állított ki Vulkánban, Szurdokon, Bodzakrasznán, Ósánczon és Gyergyóbékáson.

48 999/1912. (IV. 13.) BM.r. ; 58 320/1912. (IV. 13.) BM.kr.

${ }^{39}$ PARÁDI: A határszéli csendörség 1891-1914. op.cit. 49-51.p.

${ }^{40}$ PARÁDI: A csendőrség teendői az Osztrák-Magyar Monarchia Magyar Királysága külső határainak őrizetében. 
${ }^{41}$ PARÁDI: Az egységes állami fizetési rendszer és a szakterületi rendfokozati rendszerek a polgári magyar állam rendvédelmében.

${ }^{42}$ SZUT-1912 Titkos függelék. op.cit.

43 PARÁDI: Felderítő szolgálat az Osztrák-Magyar Monarchiában.

${ }^{44}$ PARÁDI: A határszéli csendőrség állambiztonsági feladatai.

${ }^{45}$ PARÁDI: A hátország rendvédelme 1914-1918.

${ }^{46}$ PARÁDI: Áttérés a háborús határőrizetre az első világháború elött.

${ }^{47}$ Loc.cit.

${ }^{48}$ A járásőrmesterségeket 1901-ben állították fel. A tábori csendőrség számára pedig az első utasítás az 1890-es évek első felében készült, amely lényegében azt jelentette, hogy a szervezet is ezen időszaktól állt fen legalább is a békeidőbeli előzményei.

PreSZly: op.cit. 71.p. ; SZAKÁly: 14.p.

${ }^{49}$ PARÁDI: A határszéli csendörség 1891-1914. op.cit. 85-87.p.

${ }^{50}$ PARÁDI: Az Osztrák-Magyar Monarchia Magyar Királyságának határszéli csendőrsége.

Jegyzetekben alkalmazott röviditések:

\section{MONOGRÁFIÁK, KISMONOGRÁFIÁK ÉS HASONLÓ JELLEGŰ KÖTETEK}

BÖLÖNY

\section{Clausewitz}

CsAPó: A Magyar Királyi Csendörség története 1881-1914.

CsAPÓ: Ráday Gedeon és a szegedi királyi biztosság. A betyárvilág felszámolása.

GALÁNTAI

PARÁDI: A határszéli csendörség 18911914.

PARÁDI: A magyar rendvédelem története.

PARÁDI: Pénzügyőrség és vámhivatalok a határörizetben.

PARÁDI: Csendőrség a határőrizetben.

PARÁDI: Rendőrség a határőrizetben.

PARÁDI: A Magyar Királyi Csendőrség. Az elsö magyar polgári, központositott közbiztonsági örtestület 1881-1945.

PRESZLY

REKTOR

SZAKÁLY

\section{TANULMÁNYOK}

ÖRY
BÖLÖNY József: Magyarország kormányai 1848-1975. Budapest, 1978, Akadémia. 328 p. HU-ISBN 963051242 v. /A Magyar Országos Levéltár Kiadványai, IV. - Levéltártan és történeti forrásdokumentumok, 2./ HU-ISSN 0441-4985.

- Clausewitz Karl von: Vom Kriege. [A háborúról.] Ford.: Hazai Samu. Budapest, $1917^{2}$, Atheneum. $586 \mathrm{p}$.

Csapó Csaba: A Magyar Királyi Csendörség története 1881-1914. Pécs, 1999, Pro Pannónia Kiadói Alapítvány. 186 p. HU-ISBN 9639079405. /Pannónia Könyvek./ HU-ISSN 0237-4277.

CsAPó Csaba: Ráday Gedeon és a szegedi királyi biztosság. A betyárvilág felszámolása. Pécs, 2007, Pro Pannónia Kiadói Alapítvány. 204 p. HU-ISBN 978963949887 7. /Pannónia Könyvek./ HU-ISSN 0237-4277.

- Galántai József: A Habsburg-monarchia alkonya. Az osztrák-magyar dualizmus 1867-1918. Budapest, 1985, Kossuth Könyvkiadó. 386 p. HUISBN 9630925893.

PARÁDI József: A határszéli csendőrség 1891-1914. Budapest, 1984, Határörség. 95 p.

PARÁDI József: A magyar rendvédelem története. Budapest, 1996, Osiris. 367 p. HU-ISBN 9630479583.

PARÁDI József: Pénzügyőrség és vámhivatalok a határőrizetben. Budapest, 2003, Tipico Design. 219 p. HU-ISBN 963762330 2./Rendvédelem a határokon a XIX-XX. században, 1./ HU-ISSN -

PARÁDI József: Csendőrség a határörizetben. Budapest, 2003, Tipico Design. 186 p. HU-ISBN 963762331 0. /Rendvédelem a határokon a XIXXX. században, 2./ HU-ISSN -

PARÁDI József: Rendörség a határörizetben. Budapest, 2003, Tipico Design. 266 p. HU-ISBN 963762332 9. /Rendvédelem a határokon a XIXXX. században, 3./ HU-ISSN -

PARÁDI József: A Magyar Királyi Csendőrség. Az első magyar polgári, központositott közbiztonsági örtestület 1881-1945. Budapest, 2012, Szemere Bertalan Magyar Rendvédelem-történeti Tudományos Társaság. 281 p. HUISBN 978963084794 0. /A magyar rendvédelem-történet öröksége, 2./ HUISSN 2062-8447. 51-53.p. + 93-95.p.

- Preszly Lóránd: A Magyar Királyi Csendörség története 1881-1919. Budapest, 1920, Honvédelmi Sajtóvállalat. 142 p.

- ReKTOR Béla: A Magyar Királyi Csendőrség oknyomozó története. Cleveland, Ohio, USA, 1980, Árpád Könyvkiadó Vállalat. 552 p. USA-ISBN 0934214018 .

- SzAKÁLy Sándor: A magyar tábori csendörség története 1938-1945. Budapest, 2000, Ister. 173 p. HU-ISBN 9633243248.

ŐRY Károly: A Maréchaussée-tól a Gendarmerie Nationale-ig. A Francia Csendörség történeti előzményei. Rendvédelem-történeti Füzetek (Acta Historiae Preasidii Ordinis), VII.évf. (1997) 8.sz. 75-77.p. HU-ISSN 1216-6774. A tanulmány korábbi változata 1996. október 29-én Budapesten hangzott el a Szemere Bertalan Magyar Rendvédelem-történeti Tudományos Társaság által szervezett rendvédelem-történeti tudományos konferenciasorozatnak ,A napóleoni közbiztonsági örtestület útja Párizstól - Itálián és Ausztrián keresztül 
PARÁdI: A dualista Magyarország határőrizeti rendszerének kialakulása.

PARÁDI: A Magyar Királyi Határrendőrség, a magyar határörizet szakmai vezető testülete.

PARÁDI: Áttérés a háborús határörizetre az első világháború előtt.

PARÁDI: A határszéli csendőrség állambiztonsági feladatai.

PARÁDI: A Magyar Királyi Csendőrség határőrizeti szolgálata.

PARÁDI József: A csendőrség teendői az Osztrák-Magyar Monarchia Magyar királysága külső határainak őrzésében.

PARÁDI: Az Osztrák-Magyar Monarchia Magyar Királyságának határszéli csendőrsége.

PARÁDI: Az egységes állami fizetési rendszer és a szakterületi rendfokozati rendszerek a polgári magyar állam rendvédelmében.

PARÁDI: Felderítő szolgálat az OsztrákMagyar Monarchiában.
- Budapestig” címủ VIII. konferenciáján. A publikált tanulmány az előadás javított, bővített és átdolgozott változata.

PARÁDI József: A dualista Magyarország határőrizeti rendszerének kialakulása. Belügyi Szemle, XXX.évf. (1982) 10.sz. 44-51.p. HU-ISSN 0133-6738.

PARÁDI József: A Magyar Királyi Határrendőrség, a magyar határőrizet szakmai vezető testülete. Rendvédelem-történeti Füzetek (Acta Historiae Praesidii Ordinis), III.évf. (1993) 4.sz. 21-50.p. HU-ISSN 1216-6774. A tanulmány korábbi változata 1992. szeptember 29-én Budapesten hangzott el a Szemere Bertalan Magyar Rendvédelem-történeti Tudományos Társaság által szervezett rendvédelem-történeti tudományos konferenciasorozatnak ,A dualista Magyarország rendvédelme” című IV. konferenciáján. A publikált tanulmány az előadás javított, bővített és átdolgozott változata.

PARÁDI József: Áttérés a háborús határőrizetre az első világháború előtt. Rendvédelemtörténeti Füzetek (Acta Historiae Preasidii Ordinis), IV.évf. (1994) 5.sz. 13-17.p. HU-ISSN 1216-6774. A tanulmány korábbi változata 1993. szeptember 21-én Budapesten hangzott el a Szemere Bertalan Magyar Rendvédelem-történeti Tudományos Társaság által szervezett rendvédelemtörténeti tudományos konferenciasorozatnak a „Háború, forradalom, trianon" címü V. konferenciáján. A publikált tanulmány az előadás javított, bővített és átdolgozott változata.

PARÁDI József: A határszéli csendőrség állambiztonsági feladatai. Rendvédelem-történeti Füzetek (Acta Historiae Praesidii Ordinis), XI.évf. (2005) 14.sz. 91-94.p. HU-ISSN 1216-6774. A tanulmány korábbi változata - német nyelven - 2002 februárjában Budapesten hangzott el a Szemere Bertalan Magyar Rendvédelem-történeti Tudományos Társaság Csendörség-történeti Szakosztálya által szervezett tudományos rendezvénysorozat ,A csendörség Magyarországon" című II. szimpozionján. A publikált tanulmány az elöadás javított bővített és átdolgozott változata.

PARÁDI József: A Magyar Királyi Csendőrség határőrizeti szolgálata. Rendvédelem-történeti Füzetek (Acta Historiae Preasidii Ordinis), XIX.évf. (2010) 22.sz. 77-91.p. HU-ISSN 1216-6774. A tanulmány korábbi változata 2008. október 10-én Budapesten hangzott el, a Szemere Bertalan Magyar Rendvédelem-történeti Tudományos Társaság által szervezett rendvédelemtörténeti tudományos konferenciasorozatnak ,,Másfél évszázad rendszerváltozásainak hatásai a nemzeti rendvédelmünkre" címü XXII. konferenciáján. A publikált tanulmány az előadás javított, bővített és átdolgozott változata.

PARÁDI József: A csendőrség teendői az Osztrák-Magyar Monarchia Magyar királysága külső határainak őrzésében. Rendvédelem-történeti Füzetek (Acta Historiae Preasidii Ordinis), XXI. évf. (2011) 24. sz. 100-118. p. HUISSN 1216-6774. A tanulmány korábbi változata 2009. december 3-án Budapesten hangzott el, a Szemere Bertalan Magyar Rendvédelem-történeti Tudományos Társaság által szervezett rendvédelem-történeti tudományos konferencia-sorozatnak „Csendőrség Ausztria-Magyarországon, illetve Ausztriában és Magyarországon 1849-2005” címü XXIV. konferenciáján. A publikált tanulmány az előadás javított, bővített és átdolgozott változata.

PARÁDI József: Az Osztrák-Magyar Monarchia Magyar Királyságának határszéli csendőrsége. Rendvédelem-történeti Füzetek (Acta Historiae Preasidii Ordinis), XXII.évf. (2012) 26.sz. 81-104.p. HU-ISSN 1216-6774. A tanulmány korábbi változata 2011. november 11.-én, Budapesten hangzott el, a Szemere Bertalan Magyar Rendvédelem-történeti Tudományos Társaság által szervezett rendvédelem-történeti tudományos konferenciasorozatnak ,,Militarizmus és demilitarizmus a XIX-XX. századi magyar állam rendvédelmében" címü XXV. konferenciáján. A publikált tanulmány az előadás javított, bővített és átdolgozott változata.

PARÁDI József: Az egységes állami fizetési rendszer és a szakterületi rendfokozati rendszerek a polgári magyar állam rendvédelmében. Rendvédelemtörténeti Füzetek (Acta Historiae Preasidii Ordinis), XXII.évf. (2012) 26.sz. 105-119.p. HU-ISSN 1216-6774. A ttanulmány korábbi változata 2011. november 11-én, Budapesten hangzott el, a Szemere Bertalan Magyar Rendvédelem-történeti Tudományos Társaság által szervezett rendvédelem-történeti tudományos konferenciasorozatnak ,Militarizmus és demilitarizmus a XIX-XX. századi magyar állam rendvédelmében” címü XXV. konferenciáján. A publikált tanulmány az előadás javított, bővített és átdolgozott változata.

PARÁDI József: Felderítő szolgálat az Osztrák-Magyar Monarchiában. 2749.p. In Boda József - PARÁDI József - REGÉNYI Kund Miklós (szerk.): 1872 Felderítö-szolgálati utasítás. Anleitung zum Kundschaftsdienste. Budapest, 2014, Nemzetbiztonsági Szakszolgálat - Szemere Bertalan Magyar 
PARÁDI: A hátország rendvédelme 1914- — 1918.

ZACHAR: Fejezetek az osztrák csendőrség történetéből 1849-1918.

ZACHAR: A HABSBURG-hatalom és a magyar rendvédelem.

\section{KÉZIRAT}

SUBA

\section{SZABÁLYZATOK}

SZUT-1912

SZUT-1912 Titkos függelék.

\section{JOGSZABÁLYOK}

1881/II.tc.

1881/III.tc.

1882/X.tc.

1888/XIV.tc.

1903/VII.tc.

1903/VIII.tc.

1912/LXIII.tc.

50 431/1891. (VII. 1.) BM.r.

5692/1905. (XII.29.) ME.r.

91 000/1905. (XII. 29.) BM.kr.

48 999/1912. (IV. 13.) BM.r.

58 320/1912. (IV. 13.) BM.kr.
Rendvédelem-történeti Tudományos Társaság. 441 p. HU-ISBN 97896389 8284 1. /A magyar rendvédelem-történet hagyatéka, 1./ HU-ISSN 2064-4728.

PARÁDI József: A hátország rendvédelme 1914-1918. Trianoni Szemle Évkönyv, VII.évf. (2015) 7.sz. 108-124.p. HU-ISSN 2060-2502.

ZACHAR József: Fejezetek az osztrák csendőrség történetéből 1849-1918. Rendvédelem-történeti Füzetek (Acta Historiae Praesidii Ordinis) VII.évf. (1997) 8.sz. 105-109.p. HU-ISSN 1216-6774. A tanulmány korábbi változata 1996. október 29-én, hangzott el, Budapesten a Szemere Bertalan Magyar Rendvédelemtörténeti Tudományos Társaság által szervezett magyar rendvédelem-történeti tudományos konferencia-sorozatnak „A napóleoni közbiztonsági őrtestület útja Párizstól - Itálián és Ausztrián keresztül - Budapestig" címü VIII. konferenciáján. A publikált tanulmány az előadás javított, bővített és átdolgozott változata.

ZACHAR József: A HABSBURG-hatalom és a magyar rendvédelem. Rendvédelem-történeti Füzetek (Acta Historiae Praesidii Ordinis), IX.évf. (2005) 14.sz. 146-149.p. HU-ISSN 1216-6774. A tanulmány korábbi változata 2000. november 8-án, hangzott el, Budapesten a Szemere Bertalan Magyar Rendvédelem-történeti Tudományos Társaság által szervezett magyar rendvédelem-történeti tudományos konferencia-sorozatnak ,Az ezeréves magyar rendvédelem” címü XIV. konferenciáján. A publikált tanulmány az előadás javított, bővített és átdolgozott változata.

SuBA János: Magyarország határának kitüzése és felmérése 1921-1925 (a határmegállapitó bizottságok müködése). Kézirat, (ELTE-BTK.) doktori értekezés) Budapest, 1996.

- Utasitások a Magyar Királyi Csendörség számára. Budapest, 1912, Várnay és Fia Municipia Kiadóhivatala. 384 p.

Titkos. Függelék az „Utasítások a M. Kir. Csendőrség számára” című szolgálati könyvhöz. (A hírszerző szolgálat ellátása és a kémkedés megakadályozása.) Budapest, 1912, Magyar Királyi Állami Nyomda. 41 p.

— 1881/II.tc. a csendőrségi legénység állományának a kiegészítéséröl.

— 1881/III.tc. a közbiztonsági szolgálat szervezéséröl.

- 1882/X.tc. a Magyar Királyi Csendőrség által, a törvényhatósági joggal felruházott városok kül- és belterületein való teljesítendőkről.

1888/XIV.tc. az Osztrák-Magyar Monarchiának Romániával, a monarchia két állama és Románia között fennforgott határvillongások kiegyenlítése végett, a határvonal újabb megállapítása és azzal kapcsolatos kérdések szabályozása tárgyában kötött és Bukarestben 1887. évi december 7-én, november 25.-én aláírt nemzetközi egyezmény beczikkelyezéséről.

— 1903/VII.tc. három új csendőrkerület felállításáról.

— 1903/VIII.tc. a határrendőrségről.

- 1912/LXIII.tc. a háború esetére szóló kivételes inézkedésekről.

- 50 431/1891. (VII. 1.) BM.r. a m. kir. belügyministernek 50.431. szám alatt I. Besztercze-Naszód, II. Maros-Torda, III. Csik, IV. Háromszék, V. Brassó, VI. Fogaras, VII. Szeben, VIII. Hunyad és IX. Krassó-Szörény vármegye közönségéhez intézett rendelete, az 1888. évi XIV. törvényczikkel beczikkelyezett magyar-román határegyezmény alapján kiadott határőrizeti utasitás tárgyában.

Magyarországi Rendeletek Tára, XXV.évf. (1891) I.füzet. 877-902.p.

5692/1905. (XII.29.) ME.r. a határrendőrségről szóló 1903/VIII.tc. életbe léptetéséröl.

Magyarországi rendeletek Tára, XXXIX.évf. (1905) I.füzet. 1455.p.

- $\quad 91$ 000/1905. (XII. 29.) BM.kr. valamennyi törvényhatósághoz Fiume város kivételével a határrendőrségről szóló 1903/VIII.tc. életbe léptetésének a végrehajtásáról.

Magyarországi rendeletek Tára, XXXIX.évf. (1905) I.füzet. 1455-1541.p.

48 999/1912. (IV. 13.) BM.r. határszéli külszolgálatnak átvétele a Magyar Királyi Csendőrség által.

Belügyi Közlöny, XVII.évf. (1912) 8.sz. 141-145.p.

- 58 320/1912. (IV. 13.) BM.kr. a határrendőri külszolgálat ellátása a határrendőrségi örségek megszüntetésével.

Belügyi Közlöny, XVII.évf. (1912) 8.sz. 136-140.p. 


\section{Mellékletek jegyzéke:}

I.sz. melléklet

A határőrizeti erők összetétele a határszéli csendőrség felállításakor.

II.sz. melléklet

A határszéli csendőrség diszlokációja és létszáma 1913.

III.sz. melléklet

A Magyar Királyi Csendőrség általános és a határszéli csendőrség speciális szervezeti felépítése 1913.

\section{A határörizeti erök összetétele a határszéli csendörség felállitásakor.}

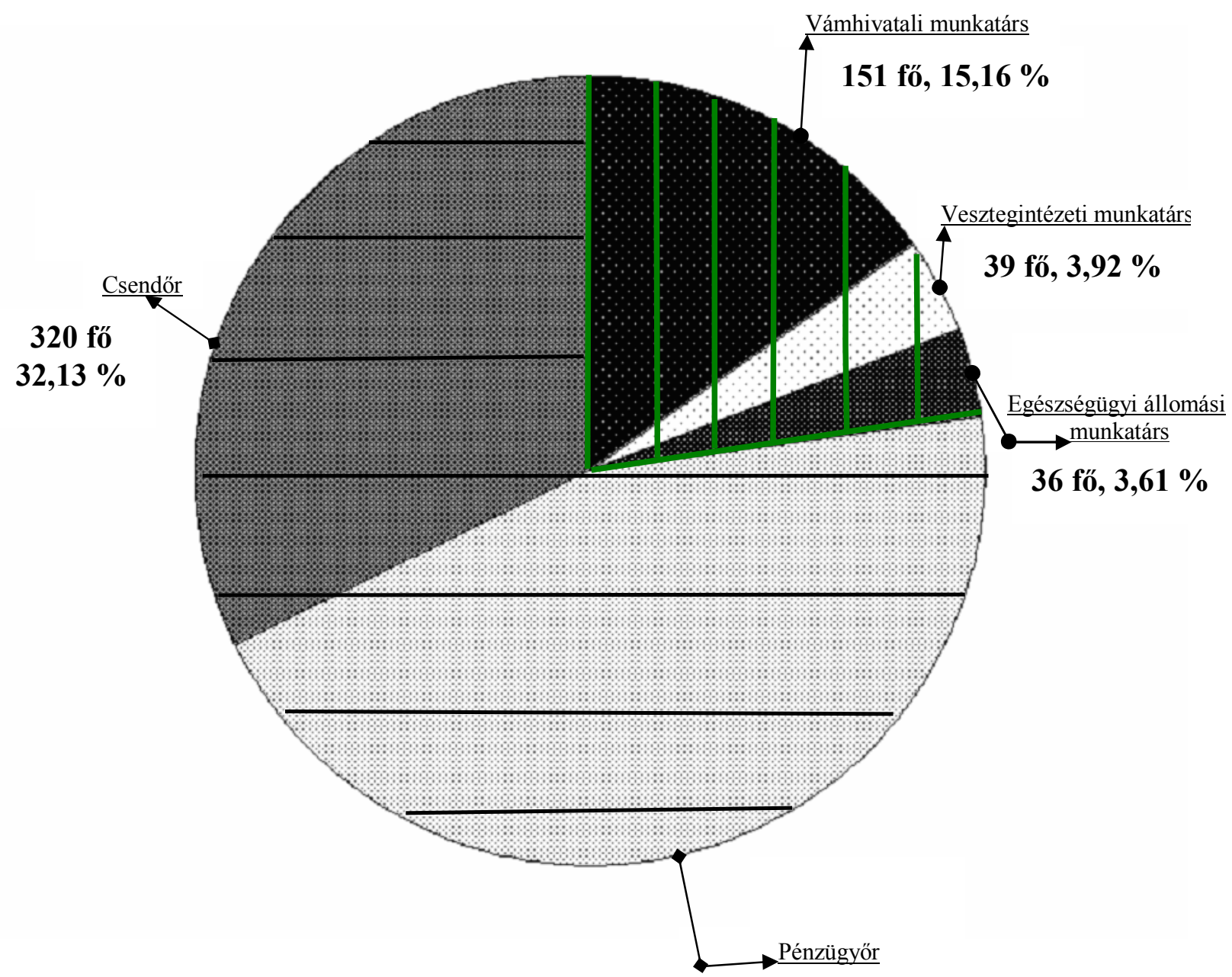

Megjegyzés:

Összesen 996 fő teljesített határőrizeti szolgálatot, melyből

450 fö, $45,18 \%$

fegyvernélküli szolgálatot látott el (függőleges csíkozás) 226 fö:

- 151 fö $(15,16 \%)$ vámhivatali munkatárs;

- 39 fö ( $3,92 \%)$ vesztegintézeti munkatárs;

- 36 fö ( 3,61 \%) Egészségügyi állomási munkatárs

fegyveres szolgálatot látott el (vízszintes csíkozás) 770 fö:

- 450 fö $(45,18 \%)$ pénzügyőr;

- 320 fö $(32,13 \%)$ csendőr.

Forrás ! - PARÁDI József: A határszéli csendőrség 1891-1914. Budapest, 1984, Határ-őrség. 95 p.

- PARÁDi József et. al. (szerk.): A magyar rendvédelem története. Budapest, 1996², Osiris. 367 p.

HU-ISBN 9630479583. 
A határszéli csendőrség diszlokációja és létszáma 1913.

\begin{tabular}{|c|c|c|c|}
\hline $\begin{array}{c}\text { kikülönített } \\
\text { törzstiszt }\end{array}$ & $\begin{array}{l}\text { szárny/ } \\
\text { szakasz }\end{array}$ & örs & létszám \\
\hline \multirow{61}{*}{$\begin{array}{l}\text { I. } \\
\text { Pancsova }\end{array}$} & \multirow[t]{10}{*}{ Pancsova } & Pancsova & 43 \\
\hline & & Borcsa & 10 \\
\hline & & Bárányos & 7 \\
\hline & & Hertelendy-falva & 7 \\
\hline & & Sándor-egyháza & 9 \\
\hline & & Beresztóc & 7 \\
\hline & & Omlód & 8 \\
\hline & & Tárcsó & 8 \\
\hline & & 5. sz. örház & 7 \\
\hline & & 2. sz. gátőrház & 7 \\
\hline & \multicolumn{2}{|c|}{ Pancsova összesen } & 113 \\
\hline & Fehértemplom & Palánk & 10 \\
\hline & \multicolumn{2}{|c|}{ Fehértemplom összesen } & 10 \\
\hline & \multirow[t]{8}{*}{ Kevevár } & Kevevára & 12 \\
\hline & & Kevepallós & 7 \\
\hline & & Temessziget & 14 \\
\hline & & 28. sz. klekk & 7 \\
\hline & & 9. sz. gátőrház & 7 \\
\hline & & Popolova-Hunka & 7 \\
\hline & & Dunadombó & 8 \\
\hline & & Gálya & 7 \\
\hline & \multicolumn{2}{|c|}{ Kevevár összesen } & 69 \\
\hline & \multirow{16}{*}{ Orsova } & Orsova & 22 \\
\hline & & Vodica & 6 \\
\hline & & Szelistye & 6 \\
\hline & & Pojana-Racheli & 6 \\
\hline & & Pojana-Sulita & 6 \\
\hline & & Csernahévíz & 8 \\
\hline & & Herkules-fürdő & 8 \\
\hline & & Pojana-Cossului & 6 \\
\hline & & Tezna & 7 \\
\hline & & Naszádos & 8 \\
\hline & & Dunaorbágy & 6 \\
\hline & & Óasszonyrét & 7 \\
\hline & & Dunatölgyes & 6 \\
\hline & & Szinice & 10 \\
\hline & & Tiszóca & 6 \\
\hline & & Sztara-Szinice & 6 \\
\hline & \multicolumn{2}{|r|}{ Orsova összesen } & 124 \\
\hline & \multirow[t]{12}{*}{ Újimoldova } & Újmoldova & 8 \\
\hline & & Ómoldova & 8 \\
\hline & & Felsőpozsgás & 7 \\
\hline & & Sisak & 8 \\
\hline & & Divécs & 7 \\
\hline & & Baziás & 9 \\
\hline & & Berzászka & 8 \\
\hline & & Kozlatelep & 9 \\
\hline & & Alsólupkó & 6 \\
\hline & & Szikesfalu & 7 \\
\hline & & Lyuborazdia & 6 \\
\hline & & Lászlóvára & 8 \\
\hline & \multicolumn{2}{|c|}{ Újmoldva összesen } & 91 \\
\hline & \multirow{8}{*}{ Karánsebes } & Ruszka & 6 \\
\hline & & Somosréve & 8 \\
\hline & & Bogoltény & 7 \\
\hline & & Cracu-Stephanului & 6 \\
\hline & & Pojana-Schitu & 6 \\
\hline & & Kupánhegy & 6 \\
\hline & & Cracu-Dragutului & 6 \\
\hline & & Tucilla & 6 \\
\hline & \multicolumn{2}{|c|}{ Karánsebes összesen } & 51 \\
\hline \multicolumn{3}{|c|}{ Pancsovai kikülönített törzstiszt összesen } & 458 \\
\hline
\end{tabular}

\begin{tabular}{|c|c|c|c|}
\hline $\begin{array}{c}\text { kikülönített } \\
\text { törzstiszt }\end{array}$ & $\begin{array}{l}\text { szárny/ } \\
\text { szakasz }\end{array}$ & örs & létszám \\
\hline \multirow{38}{*}{$\begin{array}{l}\text { II. } \\
\text { Nagyszeben }\end{array}$} & \multirow[t]{11}{*}{ Nagyszeben } & Riuszád & 7 \\
\hline & & Hanecsul & 6 \\
\hline & & Lakul Dobrun & 6 \\
\hline & & Negovanul & 6 \\
\hline & & \begin{tabular}{|l|} 
Voineagul \\
\end{tabular} & 6 \\
\hline & & Stina Groapa & 6 \\
\hline & & Vöröstorony vá. & 10 \\
\hline & & Vöröstorony vám & 17 \\
\hline & & Vöröstorony határ & 6 \\
\hline & & Stina Fedelesului & 6 \\
\hline & & Felek & 7 \\
\hline & \multicolumn{2}{|c|}{ Nagyszeben összesen } & 83 \\
\hline & \multirow[t]{5}{*}{ Szászsebes } & Szelistye & 9 \\
\hline & & Piátraalba & 6 \\
\hline & & Preája & 6 \\
\hline & & Szerecsin & 6 \\
\hline & & Dus & 6 \\
\hline & \multicolumn{2}{|c|}{ Szászsebes összesen } & 33 \\
\hline & \multirow[t]{2}{*}{ Déva } & Oása & $\overline{66}$ \\
\hline & & Déva összesen & 6 \\
\hline & \multirow[t]{14}{*}{ Petrozsény } & Petrozsény & 21 \\
\hline & & Wekerletelep & 8 \\
\hline & & Csimpa & 7 \\
\hline & & Pojánamueri & 6 \\
\hline & & Pettillai határ & 6 \\
\hline & & Szurdokszoros & 11 \\
\hline & & Vulkán & 8 \\
\hline & & Vulkánszoros & 6 \\
\hline & & St. Gemenári & 6 \\
\hline & & Coasta Lui Rossu & 6 \\
\hline & & Lupény & 8 \\
\hline & & Felsöurikány & 6 \\
\hline & & Kimpuluinyág & 7 \\
\hline & & Kimpu Mnyelului & 6 \\
\hline & \multicolumn{2}{|c|}{ Petrozsény összesen } & 112 \\
\hline & \multirow[t]{2}{*}{ Hátszeg } & Cura Ápilor & 6 \\
\hline & & Uncsukfalva & 8 \\
\hline & & Hátszeg összesen & 14 \\
\hline \multicolumn{3}{|c|}{ Nagyszebeni kikülönített törzstiszt összesen } & 248 \\
\hline \multirow{26}{*}{\begin{tabular}{|l|} 
III. \\
Brassó
\end{tabular}} & \multirow[t]{12}{*}{ Brassó } & Barcarozsnyó & 9 \\
\hline & & Rozsnyói villanytelep & 7 \\
\hline & & Predeál & 25 \\
\hline & & Alsótömös & 6 \\
\hline & & Hosszúfalú & 9 \\
\hline & & Ósánc & 6 \\
\hline & & Tükrös & 7 \\
\hline & & Garcsinvölgy & 6 \\
\hline & & Predeluc & 6 \\
\hline & & Kecskeláb & 6 \\
\hline & & Kiságpatak útk. ház & 6 \\
\hline & & Tolvajkút & 6 \\
\hline & \multirow{13}{*}{\begin{tabular}{l|l} 
Fogaras \\
\end{tabular}} & Brassó összesen & 99 \\
\hline & & Breáza & 8 \\
\hline & & Sebes & 7 \\
\hline & & Catlavei Menház & 6 \\
\hline & & Stina de Cropilla & 6 \\
\hline & & Belia Mare & 6 \\
\hline & & Vukaria Mare & 7 \\
\hline & & Alsóárpás & 8 \\
\hline & & Porumbák alsó & 7 \\
\hline & & Alsóvist & 7 \\
\hline & & Stina Seretea & 7 \\
\hline & & Bulea Menház & 6 \\
\hline & & Vistea Mare & 6 \\
\hline & \multicolumn{2}{|r|}{ Fogarasösszesen } & 81 \\
\hline
\end{tabular}




\begin{tabular}{|c|c|c|c|}
\hline $\begin{array}{c}\text { kikülönített } \\
\text { törzstiszt }\end{array}$ & $\begin{array}{l}\text { szárny/ } \\
\text { szakasz }\end{array}$ & örs & létszám \\
\hline \multirow{31}{*}{$\begin{array}{l}\text { III. } \\
\text { Brassó } \\
\text { (folyt.) }\end{array}$} & \multirow{8}{*}{ Zerest } & Zerest & 9 \\
\hline & & Felsőtörcsvár & 7 \\
\hline & & Törcsvár & 10 \\
\hline & & Almásmező & 7 \\
\hline & & Plaul Foi vadászlak & 6 \\
\hline & & Pesztera & 6 \\
\hline & & Sirnea & 7 \\
\hline & & Felsőmoecs & 7 \\
\hline & \multicolumn{2}{|r|}{ Zerest összesen } & 59 \\
\hline & \multirow{4}{*}{$\begin{array}{c}\text { Sepsiszent- } \\
\text { györgy }\end{array}$} & Kishatárhegy & 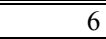 \\
\hline & & Tatárhavasszoros & 6 \\
\hline & & Magyarbodzavám & 7 \\
\hline & & Magyarbodza & 9 \\
\hline & \multicolumn{2}{|c|}{ Sepsiszentgyörgy összesen } & 28 \\
\hline & \multirow{16}{*}{$\begin{array}{r}\text { Kézdivásár- } \\
\text { hely }\end{array}$} & Esztelnek & 7 \\
\hline & & Bereck & 8 \\
\hline & & Sósmező & 11 \\
\hline & & Kecskéstelep & 6 \\
\hline & & Kishavas & 6 \\
\hline & & Leánymező & 6 \\
\hline & & Esztina sor & 6 \\
\hline & & Vajdakői örház & 6 \\
\hline & & Kovászna & 10 \\
\hline & & Kisbota & 8 \\
\hline & & Karajos & 8 \\
\hline & & Komandótelep & 6 \\
\hline & & Gelence & 9 \\
\hline & & Putnapatak & 6 \\
\hline & & Musatelep & 8 \\
\hline & & Zabolatelep & 5 \\
\hline & \multicolumn{2}{|c|}{ Sepsiszentgyörgy összesen } & 116 \\
\hline \multicolumn{3}{|c|}{ Brassói kikülönített törzstiszt összesen } & 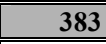 \\
\hline \multirow{34}{*}{$\begin{array}{l}\text { IV. } \\
\text { Marosvásár- } \\
\text { hely }\end{array}$} & \multirow{16}{*}{$\begin{array}{c}\text { Marosvásár- } \\
\text { hely }\end{array}$} & Gyergyótölgyes & 12 \\
\hline & & Baraszópataka & 6 \\
\hline & & Valeaszdakapatak & 6 \\
\hline & & Cibles & 6 \\
\hline & & Gyergyóholló & 7 \\
\hline & & Hágótőalja & 6 \\
\hline & & Gyergyóbékás & 10 \\
\hline & & Bisztrapatak & 7 \\
\hline & & Alsódomuk & 6 \\
\hline & & Csipkéshegy & 6 \\
\hline & & Bélbor & 6 \\
\hline & & Borszák & 7 \\
\hline & & Funtana Vinulu & 6 \\
\hline & & Moara Cinatakului & 6 \\
\hline & & Dragojásza & 6 \\
\hline & & Lomás & 6 \\
\hline & \multicolumn{2}{|c|}{ Marosvásárhely összesen } & 109 \\
\hline & \multirow[t]{9}{*}{ Beszterce } & Nagysajó & 6 \\
\hline & & Kisdemeter & 6 \\
\hline & & Borgóprund & 9 \\
\hline & & Tihuca & 7 \\
\hline & & Petrillerosiu & 6 \\
\hline & & Marosborgó & 7 \\
\hline & & Kelemencserbuk & 6 \\
\hline & & Gurahajta & 6 \\
\hline & & Dornavölgyi telep & 7 \\
\hline & \multicolumn{2}{|r|}{ Beszterce összesen } & 60 \\
\hline & \multirow[t]{6}{*}{ Naszód } & Nagyilva & 7 \\
\hline & & Kisilva & 7 \\
\hline & & Radnalajosfalva & 7 \\
\hline & & Kosna & 7 \\
\hline & & Pojánarotunda & 7 \\
\hline & & Panasuri & 6 \\
\hline & & Naszód összesen & 41 \\
\hline
\end{tabular}

\begin{tabular}{|c|c|c|c|}
\hline $\begin{array}{c}\text { kikülönített } \\
\text { törzstiszt }\end{array}$ & $\begin{array}{l}\text { szárny/ } \\
\text { szakasz }\end{array}$ & örs & létszám \\
\hline & \multirow[t]{4}{*}{ Csiksszeredai } & Kászonaltíz & 7 \\
\hline & & Kökert & 8 \\
\hline & & Lóbárc & 6 \\
\hline & & Csobáncos & 6 \\
\hline & \multicolumn{2}{|c|}{ Csíkszereda összesen } & 27 \\
\hline & \multirow[t]{9}{*}{ Gyergyósz. } & Gyimes & 12 \\
\hline & & Gyimesközéplok & 9 \\
\hline & & Csülemér & 6 \\
\hline & & Terkuca & 6 \\
\hline & & Barátos & 6 \\
\hline & & Pricsketőtelep & 7 \\
\hline & & Csügés & 7 \\
\hline & & Apahavas & 6 \\
\hline & & Kostelek & 7 \\
\hline & \multicolumn{2}{|c|}{ Gyergyósz. összesen } & 66 \\
\hline \multicolumn{3}{|c|}{ Marosvásárhelyi kikülönített törzstiszt összesen } & 303 \\
\hline \multicolumn{3}{|c|}{$\begin{array}{l}\text { KIKÜLÖNÍTETT TÖRZSTISZTEK } \\
\text { MINDÖSSZESEN }\end{array}$} & 1392 \\
\hline
\end{tabular}

Forrás ! PARÁDI József: Csendőrség a határőrizetben. 177.p. Budapest, 2003, Tipico Design. 186 p. HU-ISBN 9637623310. /Rendvédelem a határokon a XIX-XX. században, 2./ HU-ISSN - 
A Magyar Királyi Csendörség általános és a határszéli csendőrség speciális szervezeti felépítése 1913.

A Magyar Királyi Csendőrség szervezeti felépítése

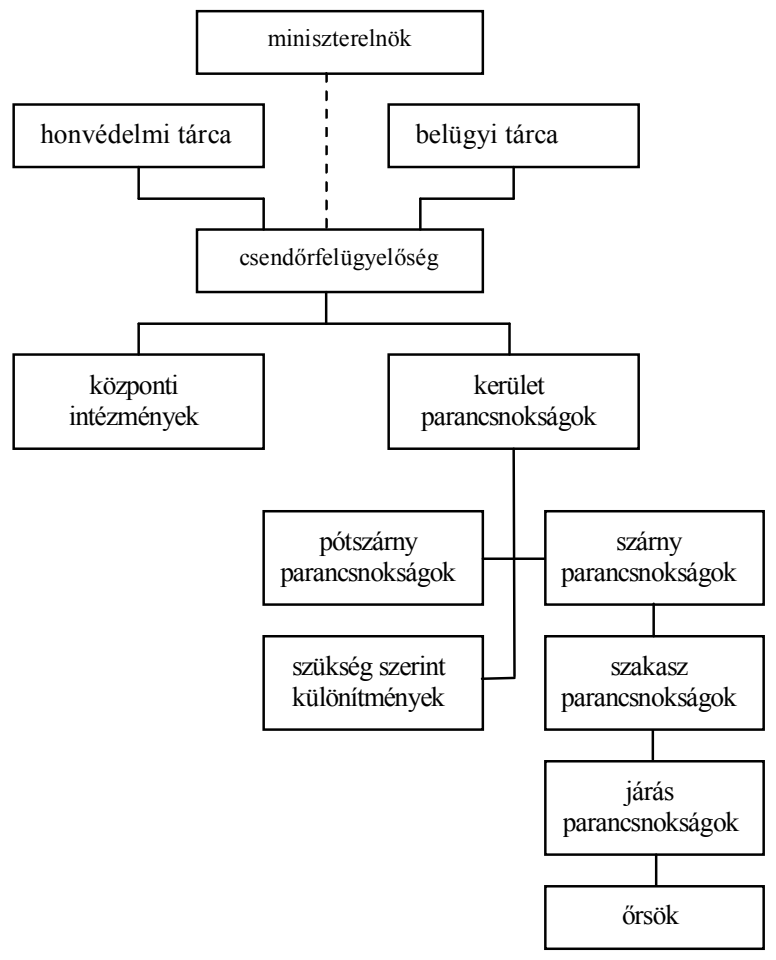

Jelmagyarázat: __
szolgálati alá- fölére
A Magyar Királyi Csendőrség határszéli csendőrségének struktúrája

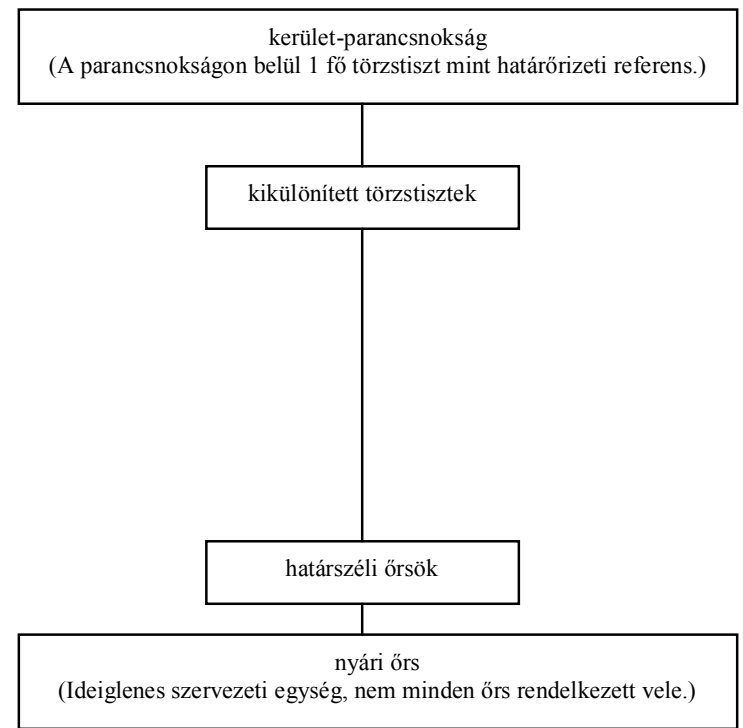

Forrás ! PARÁDI József: Csendőrség a határőrizetben. 174-175.p. Budapest, 2003, Tipico Design. 186 p. HU-ISBN 9637623310. /Rendvédelem a határokon a XIX-XX. században, 2./ HU-ISSN - 